\begin{tabular}{c}
\hline Review of \\
ECONOMICS \\
and \\
INSTITUTIONS \\
\hline
\end{tabular}

\title{
Banking Consolidation and Bank-Firm Credit Relationships: the Role of Geographical Features and Relationship Characteristics
}

\author{
Enrico Beretta \\ Bank of Italy, Genoa Branch, Economic \\ Research Unit
}

\author{
Silvia Del Prete \\ Bank of Italy, Florence Branch, Economic \\ Research Unit
}

\begin{abstract}
Using data on bank credit relationships, the paper shows that after a merger or an acquisition involving two or more banks which had previously jointly financed the same firm, the share of credit granted to the client by the consolidated intermediaries moderately decreases over three years. This does not necessarily imply a reduction of the overall credit granted to the firm, because after mergers and acquisitions the probability of diversifying the mix of lenders increases. A geographical closeness between bank and firm, or a membership of the firm in an industrial district, by reducing information asymmetries and the cost of soft information, seem to mitigate or offset the decrease in the share of credit provided by consolidated banks. By contrast, if a firm is in financial distress or located in the South of Italy, diversification is significantly enhanced.
\end{abstract}

JEL classification: G21; G34; L14; L22

Keywords: relationship banking, mergers and acquisitions, firms' agglomerations

The authors wish to express their special thanks to Massimo Omiccioli for his continuous and precious support. The authors also wish to thank Luigi Cannari, Cristina Demma, Alessandro Fabbrini, Paolo Mistrulli, Andrea Presbitero, the participants at the seminar held at the Research Department of the Bank of Italy in December 2011, and two anonymous referees for their valuable suggestions on previous versions of this study. The views expressed herein are those of the authors and do not necessarily reflect those of the Bank of Italy.

$\triangle$ Corresponding author. Address: Banca d'Italia, Florence Branch, via dell'Oriuolo 37/39, 50122 - Florence. Italy. (Phone: +39 0552493307 Fax: +39 055 2340244, E-mail: silvia.delprete@bancaditalia.it)

\section{Recommended Citation}

Beretta, E., Del Prete, S. (2013). Banking Consolidation and Bank-Firm Credit Relationships: The Role of Geographical Features and Relationship Characteristics. Review of Economics and Institutions, 4(3), Article 1. doi: 10.5202/rei.v4i3.125.

Retrieved from http://www.rei.unipg.it/rei/article/view/125 


\section{Introduction}

Over the last two decades, the Italian economy and the domestic banking sector have been affected by significant structural changes. As regards the economy, it is worth noting that since the beginning of the 1990s, the successful enterprise - even the smaller and medium-sized one - is more internationalized, more exposed to international competition, and it has a generally more balanced financial structure (Brandolini and Bugamelli, 2009; Accetturo et al., 2011). Moreover, it is often a leader in its economic specialization, having survived a more vigorous selection, further enhanced by the effects of the recent economic and financial crisis (Intesa-San Paolo, 2008 and 2009; Rabellotti et al., 2009). These major changes have inevitably conditioned credit relationships between banks and firms, since smaller exporter enterprises also need to expand the range of traditional financial products, provided by small local banks, by diversifying their borrowing towards medium and larger intermediaries, belonging to the top banking groups which also operate abroad (Ferri and Rotondi, 2006).

The banking system has undergone important changes, too. The organization of local credit markets has changed considerably as a result of technological innovation, and especially following the numerous mergers and acquisitions (M\&As) among banks, even those with local reach. Between 1997 and 2006 the Italian banks performed more than 200 mergers and around 140 acquisitions, involving a large part of the banking system's total assets (Bank of Italy, 2007). In the subsequent period, during the first financial turmoil and the following 2009-crisis, the consolidation process continued to a lesser extent: between 2007 and 2012 Italian banks were involved in around 130 mergers. Following this process, the number of Italian banks narrowed from 937 in 1997 to 706 at the end of 2012. The consolidation of the banking system has increased the average size of banks, thus modifying the organizational model of the lending process and often centralizing the decision-making powers. At the same time, larger intermediaries have been assisted in the collection of local information by the availability of more sophisticated internal rating systems (Cannari et al., 2010). Nevertheless, the increasing number of bank branches in local markets has led to large banks being geographically closer to their customers. Indeed, even if the number of Italian banks decreased due to the intense M\&A activity, since 1997 the branch network increased up more than 10,000 branches till 2008, exceeding 34,000 units. Then, the financial crisis caused a downward trend in bank branches during the subsequent years in order to contain operational costs.

However, there is fairly widespread concern that the banking consolidation process, with growth in bank size and less intensive relationship lending, could have had a negative impact on bank-firm credit relations, especially as regards small and medium-sized enterprises (SMEs), due to the implementation of rating methodologies. One of the most common 
signs is that bank M\&As have increased the organizational distance between branches and headquarters, potentially producing a departure of decision-making powers from the local markets and thus generating a substantial reduction in the exposure of single banks in terms of the total credit granted to their clients, or an interruption of specific credit relationships in order to enhance diversification. These post-consolidation strategies have mainly penalized relationship lending. ${ }^{1}$

The main purpose of this paper is to investigate whether - other things being equal - the share of each financing bank on the total amount of credit from which a firm benefits significantly changes following the involvement of its financing banks in M\&As. To this end, our study analyses the single bank-firm credit relationships, distinguishing between banks that were involved in the consolidation process and those that were not. By using this approach, the paper differs from the existing empirical literature, which has studied changes in total credit at firm level after the M\&As of the financing banks.

The share of loans each bank lends to a firm relative to the total amount of credit granted is in our data the best proxy to capture the strength of exclusivity in credit relationships between banks and firms. ${ }^{2}$ On this point some papers show that, especially during financial turmoil, firms with a single-financing bank or with fewer lenders have been the best protected in the event of a reduction in credit availability (Gobbi and Sette, 2013). We could also expect that more concentrated credit relationships with only a few banks will be more likely where the enforcement of loan contracts is more efficient: in other words, multiple banking relationships are more

1 The definition of relationship banking is not unique in the literature and the ways to identify it can be very different. Some theoretical contributions have emphasized the ways in which credit has been granted, and the various techniques applicable to lending under the assumption that there are technical forms of finance more relationship-based than others which are more transaction-based (Berger and Udell, 2002 and 2006). Other strands of theoretical and empirical research have emphasized the aspect of the exclusivity and duration of the credit relations between bank and firm (Degryse and Ongena, 2001 and 2007), by using the number of financing banks, the share of credit granted by the main bank, the status of "hausbank" of the lending intermediary or the duration of the relationship (Ongena and Smith, 2001). For a schematization of the definition of relationship lenders, see Boot (2000). Boot distinguishes two specific characteristics to identify relationship banking: namely, a) the bank invests in soft information, and b) it exploits that information through personal interaction with borrowers.

2 In the empirical literature the strength of the credit relationships has often been measured using as a proxy the duration of the relationships between banks and firms. Indeed, some papers found that long-term loans, which allow banks to accumulate more soft information, are characterized by lower funding costs and collateral requirements and more credit availability; see, among others, Herrera and Minetti (2007), Petersen and Rajan (1994), Degryse and Van Cayseele (2000). As we better clarify later (see Section 3), we focus our attention only on short-term loans, more reactive to M\&A events; so, in our data, the share of credit granted to each firm is the best proxy to measure the strength of the link between lenders and borrowers. 


\section{Figure 1 - Bank-Firm Credit Relations and the Effects of Bank M\&As}

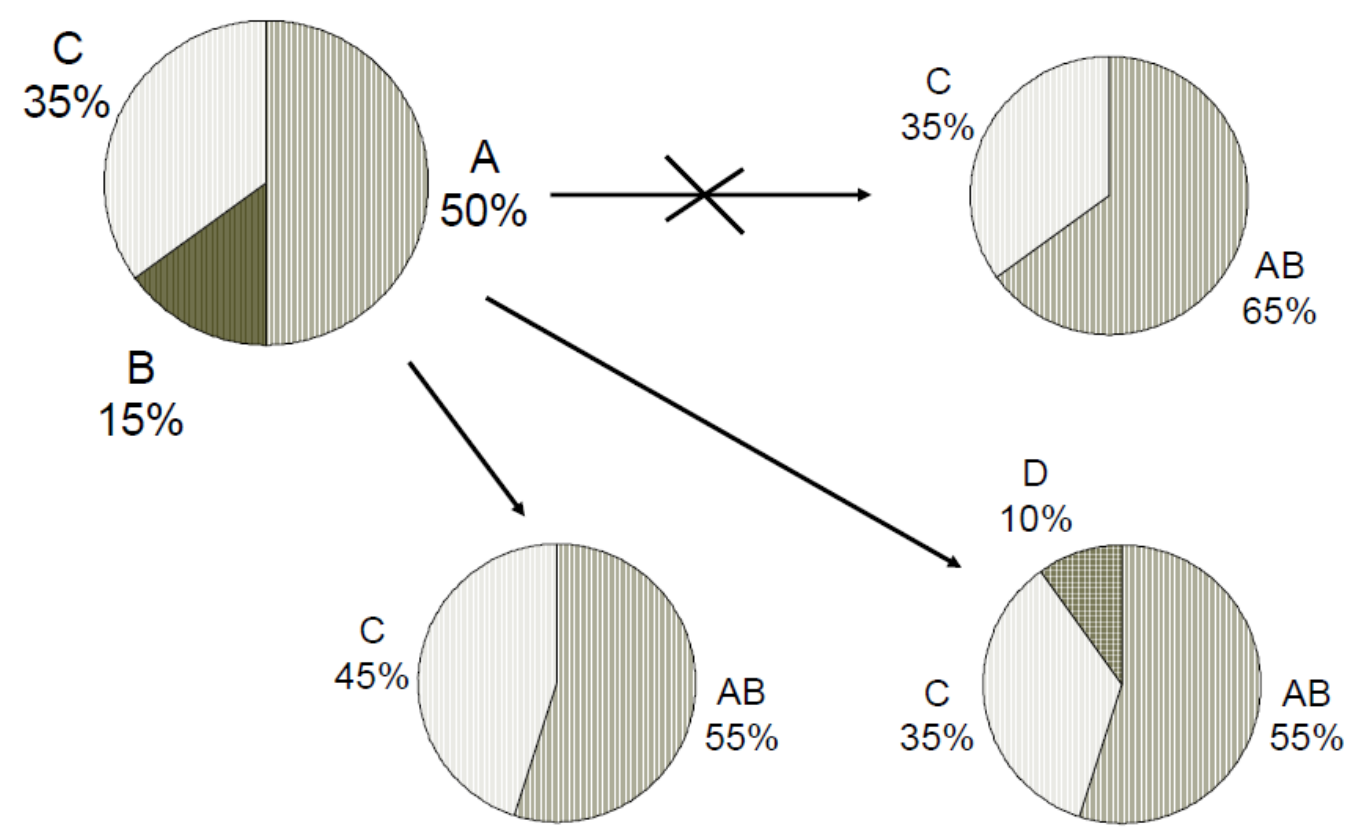

In this example the financing of the company is divided between the three financing banks $(A, B$, and $C)$, and there is also a main bank (bank $A$ ). After the merger between banks $B$ and $A$, the possible scenarios are different. In the first case (very unlikely), the credit share of the intermediary resulting from the aggregation is exactly equal to the sum of the previous shares of banks A and B. In a second case, the bank resulting from the merger, in order to reduce the excessive concentration of its portfolio towards firm $\mathrm{i}$, will select some lines of credit, reducing the overall exposure, in favour of the other banks (e.g. intermediary C). In the third case, finally, the strategy of reducing the risk of exposure towards the same client followed by consolidated banks $(A$ and $B)$ is compensated by the entry of a new bank financing firm i (bank D).

common than single ones when banks have liquidity problems or when riskier projects require financing (Detragiache et al., 2000).

The share of credit granted by each bank to the firm represents an equilibrium point between the preferences on the demand and the supply side, and it can also be affected by features related to the context in which the agents operate (concentration, market competition and structure, distanceproximity, etc.). Banking re-organizations stemming from M\&As, which may affect these factors, can change the optimal degree of concentration of single credit relations ${ }^{3}$ The adjustment, subsequent to the exogenous M\&A event, should be the more intense the higher is the number of consolidated banks that previously financed the same firm. This hypothesis can generate credit relationships between the firm and the newly consolidated bank that are too concentrated and possibly not compliant with banking regulations, so as to enhance diversification strategy. Therefore, it is plausible to observe

\footnotetext{
3 Although we are aware that the concentration of bank-firm credit relations is only one of the features of relationship lending, as already mentioned, we study the evolution of this indicator since it represents one of the few "hard" characteristics that we are able to measure in a rather precise way, by having the chance to use data on single credit relationships.
} 
a lesser commitment towards the same client, mainly from banks that had provided the largest share of its finance prior to the M\&A (see Figure 1 for a schematic example of the alternative hypotheses). One can expect that incentives to diversify credit relationships may also arise from the demand side, in order not to excessively restrict the mix of the lenders and to ensure a wide range of funding sources. ${ }^{4}$

A second specific aim of the paper is to investigate whether the process of banking consolidation had different effects on the degree of credit concentration relative to several kinds of firms, especially more opaque ones (for which the gathering of soft information is crucial), or those closest to the branches of the financing bank or those located in district areas (generally characterized by closer credit relations). A priori, in these cases one could expect different effects, reflecting heterogeneous behaviour both for the bank and for the client.$^{5}$ Taking advantage of the heterogeneity of single bank-firm credit relations, our dataset allows us to build new variables that can affect the extent of the relationship lending (such as the geographical proximity of the parties, the localization of the firm in an industrial district, or its localization in Southern regions, and its financial riskiness). By this new empirical approach we differ from most of the existing literature, which had mainly focused on the different effect of firm size.

Third, the analysis is enriched with qualitative evidence on the determinants of M\&As on the evolution of all bank-firm credit relationships, distinguishing the hypothesis of "dropping" with respect to "switching" to other lenders. This allows us to show the extent to which the change in the degree of concentration of single credit relationships actually produces a selection of borrowing firms, or instead generates a simple change in the set of firm lenders, with a re-distribution of the total credit among them.

Last but not least, the innovative contribution of our paper also consists in a new methodological approach in managing data. Indeed, in the econometric exercise we do not use a classic panel of bank and firm relationships, but we use time periods of three years in which we evaluate the effects of bank M\&As on the degree of concentration of single bank-firm credit rela-

${ }^{4}$ It is not an easy task to determine analytically the extent to which the overall result depends on a choice of banks or firms, since we observe an equilibrium point emerging from a bargain between the parties. Nevertheless, the joint use of credit "actually used" and "simply granted" helps to identify the main cause. To enrich the empirical evidence on the different roles of supply and demand, the analysis will be detailed by disaggregating different characteristics of the credit relations or of the borrowing firms. For example, more opaque firms (more distant from the bank, smaller, riskier, active in the South) should benefit from more focused credit relations; in the same way, banks that invest more in monitoring their clients should prefer more concentrated relationships.

5 On the one hand, in district areas more established relationships between banks and firms can mitigate the selection of credit relations post-M\&As; on the other hand, the close relations among firms belonging to the same district may produce a sort of domino effect, on the basis of which one firm's insolvency can spread more quickly to other firms, leading to the opposite effect. 
tions. In each three-year period we build bank pro-forma balance sheets to obtain comparable consolidated banks in each specific interval. Then, the new pro-forma observations, used to compare the change of bank share in single firm credit relationships at each time break, are employed in pooled estimates, in order to exploit all information on progressive mergers among banks that occurred during each reporting period. This new methodological approach has the advantage of avoiding distortions due to using pro-forma units over a too wide a period, as the last decade, during which the consolidation process among banks has been very intense.

The main results of this paper can be summarized as follows. In case of mergers involving several banks that were financing the same firm before the deal, we find that over a three-year period the share of credit jointly provided by the consolidated banks significantly decreases relative to other lenders. However, the reduction in the degree of concentration of each credit relation, following bank M\&As, is small (less than a percentage point) and mainly restricted to those consolidated banks that were already financing the same client. Firstly, this finding implies the implementation of diversification strategies in lending relationships by consolidated banks; secondly, it is also plausible that bank M\&As' shocks increase the incentive for firms to diversify credit relationships in order to reduce their risk of liquidity and of banking "hold-up". Taking into account specific territorial features of a firm or other characteristics of the single bank-firm relationship, which may better account for asymmetric information between the parties, we find that the share of credit provided by each bank in single firm relationships declines to a lesser extent under the hypothesis of consolidated bank branches closer to the borrowing firms, or in case of relationships with firms belonging to local industrial districts, or located in areas with few negative externalities (as in the Centre-North regions), or characterized by good performance, in terms of finance and profitability. Sector-specific features seem not to matter; particularly, in the case of high-technology firms which, sharing similar opaqueness, do not show any differential effects in credit relationships with respect to other firms in case of M\&As involving their financing banks.

The rest of the paper is organized as follows. In Section 2 we summarize the findings of the main branches of the literature on bank M\&As and relationship banking, and especially on credit to district firms. Section 3 describes the empirical strategy employed in the econometric analysis, the new methodology used to build the dataset, and our main data sources, as well as the variables used in the empirical analysis. In Section 4 we show and discuss our main findings, especially with regard to the differential effects for bank-firm credit relationships characterized by the geographical proximity of agents and for firms belonging to economic districts. Section 5 shows the results of a multinomial analysis on the determinants explaining the small change in the share of credit jointly provided to the same firm by 
consolidated banks. Section 6 concludes.

\section{Related Literature}

This paper is related to the literature on the effects of M\&As on bank lending. By using individual data on bank-firm credit relationships, it innovates this branch of research providing empirical evidence on the impact of the banking consolidation process on the degree of credit concentration of individual borrower-lender relations, rather than analysing changes in the overall credit at firm level.

The issue is especially relevant to the Italian economic system based on SMEs, often organized in economic agglomerations and known as industrial districts (Becattini et al., 2009; Signorini, 2000; Signorini and Omiccioli, 2005; Iuzzolino, 2005). This kind of analysis also has many policy implications, providing some insights into the broader issues of the role of credit in local development. The concern that consolidated banks may reduce their propensity to lend to firms has increased during the recent crisis, especially for smaller and more opaque firms, conditioning their growth and the implementation of good industrial projects.

The empirical literature on the impact of mergers on bank lending is wide and the most common result is that large consolidated banks generally reduce their exposure towards small firms in particular (Focarelli et al., 2002 and Berger et al., 1998). However, there could be some reactive effects in the long-term, with new banks entering the market or with other competitors (rival banks), which could mitigate or compensate the effect of small firms being rationed (Bonaccorsi di Patti and Gobbi, 2001). Evidence for Italy on firm credit and balance sheet data also showed the sensitivity of credit (and, to a lesser extent, of cash flow and investment expenditure) to the lending shocks stemming from bank M\&As. However, the results demonstrate that the effect is restricted to the short-run, whereas it tends to narrow in the medium-term (Bonaccorsi di Patti and Gobbi, 2007). Moreover, these negative effects on corporate finance often differ according to the kind of firm (smaller, riskier), and to the presence of a main lending bank or a smaller number of lenders. This underlines the importance of the "special" bankfirm relationship in mitigating the post-M\&A shock.

To the best of our knowledge, in several studies focused on M\&A effects on corporate lending, there is still no direct evidence of the impact of such re-organizations on individual bank-firm credit relationships. Due to lack of data, the empirical literature has so far devoted little attention to the determinants and effects explaining the banks' tendency to exclusivity in establishing credit relationships with firms. It is especially important to point out how this might be a result of changes due to the consolidation process among intermediaries, following the re-organization of banks or local markets. An exception is presented by Sapienza (2002) who, using data on 
bank-firm relations, shows that the acquisition of a small bank by a larger one tends to increase the probability that the target bank's credit relationships will be interrupted. These results seem to suggest that the consolidation process would have produced not only the diversification of credit relationships but also a screening of existing relationships.

The level of concentration of each bank-firm lending relation is an interesting feature to investigate in the empirical analysis, since it has the advantage of being easily quantifiable. The theoretical and empirical literature has shown that more focused and closer relationships between banks and firms seem to increase banks' monitoring of client creditworthiness, reducing information asymmetries and the likelihood that firms, even if in financial distress, may incur a bankruptcy. In contrast, high concentration in credit lines could also have negative effects, both for banks (increased client risk, regulatory constraints, soft budget constraint on the borrowers) and for firms (increased liquidity risk and bank hold-up). In this regard, Carmignani and Omiccioli (2007) argue that the overall effect of more concentrated banking relationships reduces the probability of a firm's liquidation but increases the probability of financial distress. This result may help explain the widespread existence of multiple but asymmetric banking relationships in Italy, as in other European countries, as a sort of "insurance policy" for firms against liquidity risk.

The high concentration of single credit lines, even if this can increase the risk of hold-up for borrowers, may improve the relevance of the information gathered by lenders, with advantages both for banks and firms, mainly during an economic crisis or financial turmoil. Therefore, the optimal level of bank exposure in credit relationships (and thus the need to diversify the firm's portfolio following a merger or acquisition) depends on the trade-off between the benefits of diversification and the cost of collecting (soft) information, especially on small and opaque borrowers. Based on this trade-off, recent contributions have emphasized that the concentration of credit relationships among few intermediaries (which affects the extent of relationship lending) may depend on changes in market competition (Presbitero and Zazzaro, 2011), also generated by the banking aggregation process ${ }^{6}$ When the bank has a higher incentive to behave like a rent-seeker and to hold-up the client, then it is more likely that after M\&As the degree of exclusivity of the credit relationship will conflict with the risk of an excessive exposure towards a single client or a specific economic sector, offsetting the benefit of collecting and using private information acquired through relationship lending. Whenever, on the contrary, the bank follows a strategic

\footnotetext{
6 The latter approach recognizes the dual nature of relationship banking: "investment", which requires that the asset of soft information acquired during the relationship is used to extract the maximum rent from borrowers (Petersen and Rajan, 1995), and "strategic", which suggests that more relationship-based banks take advantage from soft information gathering, and they use this kind of private information to compete in the market with large banks with more transaction-based credit relations.
} 
approach to relationship lending, taking a comparative advantage from the soft information gathered, the higher concentration in credit lines - as a consequence of the banking consolidation process - may provide a chance to further enhance closer relationships with firms and then to increase soft information added value. In this way, consolidated banking groups could - directly, through the increase of power delegated to branch managers, or indirectly through their subsidiaries closer to firms at local level - preserve credit relations, especially with small and opaque clients.7

Therefore, the link between banking consolidation and the degree of exclusivity in the credit relationships, measured by lenders' concentration, is not uniquely determined but depends on prevalent bank and firm behaviour, both in time and in space. On this issue, a recent study by Degryse et al. (2011) tries to assess the impact of bank mergers on small-business lending, in terms of disruption of credit relationships or credit continuation, distinguishing between cases of single or multiple lending. The results of the analysis, conducted on a sample of banking relationships involving Belgian firms, show that consolidated banks have a high rate of discontinuity of financial relationships with their clients in the case of sngle and multi-lending, especially if banks were acquired. Given the homogeneity of such data with our dataset, focused as in Degryse et al. (2011) on matched bank-firm relations, and not on the overall credit at firm-level, in our econometric exercise we investigate not only the impact of M\&As on the degree of credit concentration of each relationship but also what happens as a result of such events to the overall mix of banking relationships, both in terms of interruption or the intervention of other lenders.

With particular regard to spatial heterogeneity, in the context of business agglomerations, the issue of exclusivity of relationships and credit concentration seems even more relevant to study. To this end, exploiting the variability in the characteristics of the firm or in credit relationships (e.g. distance, territorial and sector specialization of firms, etc.), we try to better qualify the features of the relationships that can approximate information asymmetries and therefore capture more accurately the extent of relationship banking.

Yet, in connection with such specific aspects, the empirical literature has not identified a clear-cut "district effect" in the Italian local credit markets (Baffigi et al., 2000; Pagnini, 2000; Finaldi Russo and Rossi, 2001). From a theoretical point of view, in district areas the link between firms and lenders should be special for several reasons (Pagano, 2000). On the one hand, bank credit is the main source of external finance for such small enterprises; on the other hand, the close link between district firms - often organized

\footnotetext{
7 Beretta and Del Prete (2007), in an analysis on M\&A effects on lending to SMEs, show that bank mergers cause an increase of credit granted to larger firms, while acquisitions, which preserve the independence of the target, even if under a parent's common governance, seem to enhance the specialization of the acquired bank in small-business lending.
} 
in networks or interconnected by long-lasting subcontracting relationships - requires a thorough knowledge of customers, providers and specific local features. This can generate a comparative advantage for small local banks, organizationally less complex and more likely to enhance soft information, which is pivotal in small-business lending, especially in the case of more opaque firms (Alessandrini and Zazzaro, 2009; Alessandrini et al., 2008). It is therefore plausible that in the case of operational proximity between bank and firm, and of other features that enhance the soft information (smaller enterprises, district firms, etc.), credit relationships would show a higher concentration of credit, generated by a strategic approach followed by agents, since the cost of loss of information associated with diversification strategies is higher. The degree of concentration of credit lines may also be affected by other relationship features or firm characteristics, which could mitigate information asymmetries between lenders and borrowers. Different impacts on credit concentration stemming from the banking consolidation process may also depend on other factors, such as firm localization in riskier areas (e.g. in the South of Italy), higher financial fragility of the firm, or high-tech businesses with greater volatility in terms of profits and assets. In the latter case, Micucci and Rossi (2011) show that lending relationships between innovative enterprises and their main lenders last longer and have greater scope economies, even if with a lower credit concentration, probably in order to mitigate the risk of hold-up.

Taking into account the trade-off between the benefits and costs of the concentration of bank-firm relationships, a priori the overall effect of an exogenous shock arising from bank consolidation is ambiguous and depends on the degree of information asymmetry between the parties and how some specific relational characteristics may attenuate or enhance such asymmetry. So, consolidated banks may have implemented a strategic approach to improve soft information gathering through decentralization of decisional powers to the local level to balance the increased organizational complexity (Beretta and Del Prete, 2012), as well as to preserve more concentrated credit relationships and the value of the private information acquired on the borrowing firm. Conversely, large consolidated banks may have adopted strategies to centralize decision-making powers and to diversify their loan portfolio by economic sector and firm size, so as to reduce the risk of excessive credit concentration following the consolidation process. At the same time, less concentrated credit relationships after bank M\&As could also be a firm's reaction to reduce hold-up and contain liquidity risks, which naturally grow as a result of such banking reorganizations. 


\section{Data and Methodology}

\subsection{The Analytic Approach}

The analysis was conducted at bank-firm level, focusing on the share of credit granted by bank $j$ on the total loans received by the firm $i$ :

$$
\text { Share }_{j, i, t}=L_{j, i, t} / \sum_{j} L_{j, i, t}
$$

We examined changes of this share in a three-year period. We can expect this share to narrow for the banks that were involved in mergers or acquisitions. This is particularly true if, between the banks that have merged, two or more of them were jointly financing the same company at the beginning of the three-year period. The time span of three years is the one generally identified by the literature on $M \& A s$ as the transition period, in which the impact of the reorganization is felt..$^{8}$

The database includes three-year periods in which we evaluated the effects of M\&As on bank-firm lending relationships. The period under analysis ranges from 2002 to 2009; although we have considered sub three-year periods to study changes in credit relations. Indeed, the database is constructed in steps: we firstly created sets (blocks) of observations relating to each pair of years $t-3$ and $t$ (1999-2002, 2003-2006, ..., 2006-2009), and then we used them in pooled estimates. With regard to the banks, it was necessary to ensure the comparability of the credit share at the beginning and at the end of each three-year period $\left(\right.$ Share $_{j, i, t-3}$ and Share $_{j, i, t}$ ). So, we created pro-forma financial balance sheets: both for the year $t-3$ and $t$; the data for each bank $j$ were replaced by the sum of those of all banks that during the three years have been acquired or merged in the same consolidated bank. In this way, we did not have to measure changes in the credit share simply due to accounting effects, and we were able to capture the real differential impact of the reorganization. ? $^{\text {? }}$

The Methodological Appendix provides detailed information on the methodology followed in building the dataset. The main reason that led us to prefer this new methodological approach, rather than using a classic panel,

8 On the use of a three-year dummy to identify the transition period for M\&A effects, see the paper by Focarelli et al. (2002). The effects, in terms of portfolio restructuring, usually take more than one year to arise. However, we have conducted also estimations based on two-year transition period and the main results remain unchanged.

9 In order to measure the effects of different types of bank aggregation, the construction of pro-forma financial statements was necessary not only for mergers, as it is usual in the empirical literature, but also for acquisitions. So, each bank that between $t-3$ and $t$ has made mergers and/or acquisitions has been replaced, at time $t$, by the sum of itself and its acquired banks and, at time $t-3$, by the sum of itself and all its targets in M\&As of the following three years. For homogeneity, in the econometric estimates, the bank fixed effect was calculated on the pro-forma unit constructed in this way. 
Table 1 - Descriptive Statistics on the Estimation Sample (1)

\begin{tabular}{|c|c|c|c|c|c|c|}
\hline \multirow[t]{2}{*}{ Variables } & \multicolumn{3}{|c|}{ Full sample } & \multirow{2}{*}{$\begin{array}{l}\text { Firms in the } \\
1^{\text {st }} \text { quartile } \\
(2) \\
\text { Mean }\end{array}$} & \multirow{2}{*}{$\begin{array}{c}\text { Firms between } \\
1^{\text {st }} \text { and } 3^{\text {rd }} \\
\text { quartile (2) } \\
\text { Mean }\end{array}$} & \multirow{2}{*}{$\begin{array}{l}\text { Firms in the } \\
4^{\text {th }} \text { quartile } \\
(2) \\
\text { Mean }\end{array}$} \\
\hline & Mean & Median & Std. dev. & & & \\
\hline $\begin{array}{l}\text { Number of financing banks at firm- } \\
\text { level }\end{array}$ & 10.51 & 10.00 & 4.62 & 8.36 & 10.20 & 13.27 \\
\hline $\begin{array}{l}\text { Short-term loans for each bank-firm } \\
\text { relation ( } \mathrm{mln} . €)\end{array}$ & 0.49 & 0.13 & 2.64 & 0.21 & 0.38 & 0.99 \\
\hline $\begin{array}{l}\text { Credit lending share of each bank }(\% \text {, } \\
t)\end{array}$ & 9.67 & 4.73 & 14.48 & 12.10 & 9.70 & 7.17 \\
\hline $\begin{array}{l}\text { Lagged credit lending share of each } \\
\text { bank }(\%, t-3)\end{array}$ & 9.75 & 4.44 & 14.78 & 12.21 & 9.77 & 7.25 \\
\hline $\begin{array}{l}\text { Delta of the credit lending share of } \\
\text { each bank in each 3-year period (perc. } \\
\text { points) }\end{array}$ & -0.08 & 0.00 & 10.18 & -0.11 & -0.07 & -0.08 \\
\hline Average firm sales (mln. $€$ ) & 78.22 & 20.21 & 775.22 & 7.76 & 22.20 & 260.74 \\
\hline Firm ROA (\%) & 5.12 & 4.63 & 5.88 & 4.34 & 5.31 & 5.50 \\
\hline Firm leverage (value) (3) & 7.95 & 5.83 & 6.19 & 8.40 & 8.07 & 7.26 \\
\hline Firm rating (range: $1-9$ ) & 5.10 & 5.00 & 1.59 & 5.28 & 5.11 & 4.90 \\
\hline $\begin{array}{l}\text { Share of closer credit relations } \\
\text { (proximity of bank branches to the } \\
\text { firm's headquarters) }\end{array}$ & 0.56 & 1.00 & 0.50 & 0.57 & 0.54 & 0.57 \\
\hline $\begin{array}{l}\text { Share of credit relations with district } \\
\text { firms }\end{array}$ & 0.11 & 0.00 & 0.31 & 0.14 & 0.11 & 0.07 \\
\hline $\begin{array}{l}\text { Share of credit relations with mutual } \\
\text { banks }\end{array}$ & 0.06 & 0.00 & 0.23 & 0.06 & 0.06 & 0.05 \\
\hline $\begin{array}{l}\text { Share of credit relations with banks } \\
\text { involved in M\&As; HP: } D_{M A}=1\end{array}$ & 0.53 & 1.00 & 0.50 & 0.55 & 0.53 & 0.52 \\
\hline $\begin{array}{l}\text { Share of credit relations with banks } \\
\text { involved in M\&As and previously } \\
\text { jointly financing the same firm; HP: } \\
\text { D }_{\text {MAMULTI }}=1\end{array}$ & 0.05 & 0.00 & 0.23 & 0.04 & 0.05 & 0.07 \\
\hline Bank total assets (mln. $€$ ) & 54,156 & 23,796 & 61,987 & 54,816 & 54,464 & 52,879 \\
\hline Bank ROA (\%) & 0.95 & 0.92 & 0.73 & 0.96 & 0.95 & 0.93 \\
\hline Bank risk (bad loans/total loans) (\%) & 3.43 & 2.82 & 2.81 & 3.57 & 3.41 & 3.35 \\
\hline $\begin{array}{l}\text { Loan Herfindahl Index at province- } \\
\text { level (range } 0-10,000 \text { ) }\end{array}$ & 657.43 & 622.19 & 245.94 & 661.28 & 661.96 & 644.53 \\
\hline p.m. & & & & & & \\
\hline Obs. (bank-firm-year) & 712,005 & 712,005 & 712,005 & 178,015 & 355,986 & 178,004 \\
\hline
\end{tabular}

(1) Descriptive statistics are obtained on the 712,005 obs. used in the baseline estimation based on the share calculated on the credit actually used by firms. (2) The quartiles are calculated on the distribution of the overall total sales of firms. (3) Firm leverage has been cleaned of outliers, censoring any observations lower than the 5th percentile and greater than the 95th percentile of the distribution. 
Table 2 - Variables Employed in Estimations, by Year (1) (mean values)

\begin{tabular}{|c|c|c|c|c|c|c|c|c|c|}
\hline Variables & 2002 & 2003 & 2004 & 2005 & 2006 & 2007 & 2008 & 2009 & $\begin{array}{c}\text { Mean } \\
2002-09 \\
\end{array}$ \\
\hline $\begin{array}{l}\text { Number of financing banks at firm- } \\
\text { level }\end{array}$ & 10.07 & 11.00 & 10.34 & 11.36 & 11.05 & 10.07 & 9.78 & 9.77 & 10.51 \\
\hline $\begin{array}{l}\text { Short-term loans for each bank-firm } \\
\text { relation ( } \mathrm{mln} . €)\end{array}$ & 0.43 & 0.41 & 0.41 & 0.39 & 0.47 & 0.57 & 0.67 & 0.58 & 0.49 \\
\hline $\begin{array}{l}\text { Credit lending share of each bank } \\
(\%, t)\end{array}$ & 9.79 & 9.19 & 9.43 & 8.70 & 9.48 & 10.36 & 10.60 & 10.29 & 9.67 \\
\hline $\begin{array}{l}\text { Lagged credit lending share of each } \\
\text { bank }(\%, t-3)\end{array}$ & 9.50 & 9.35 & 9.84 & 8.72 & 9.59 & 10.52 & 10.53 & 10.37 & 9.75 \\
\hline $\begin{array}{l}\text { Delta of the credit lending share of } \\
\text { each bank in each 3-year period } \\
\text { (perc. points) }\end{array}$ & 0.29 & -0.16 & -0.40 & -0.03 & -0.11 & -0.16 & 0.06 & -0.09 & -0.08 \\
\hline Average firm sales (mln. €) & 58.14 & 59.34 & 62.49 & 70.07 & 79.61 & 97.97 & 96.07 & 102.91 & 78.22 \\
\hline Firm ROA (\%) & 6.09 & 5.79 & 4.97 & 4.88 & 4.68 & 5.09 & 5.39 & 4.55 & 5.12 \\
\hline Firm leverage (value) (2) & 8.37 & 8.24 & 8.11 & 8.07 & 7.85 & 7.93 & 8.10 & 6.94 & 7.95 \\
\hline Firm rating (range: 1-9) & 5.03 & 5.05 & 5.05 & 5.06 & 5.15 & 5.26 & 5.17 & 4.99 & 5.10 \\
\hline $\begin{array}{l}\text { Share of closer credit relations } \\
\text { (proximity of bank branches to the } \\
\text { firm's headquarters) }\end{array}$ & 0.57 & 0.57 & 0.57 & 0.55 & 0.59 & 0.58 & 0.51 & 0.50 & 0.56 \\
\hline $\begin{array}{l}\text { Share of credit relations with } \\
\text { district firms }\end{array}$ & 0.12 & 0.12 & 0.12 & 0.11 & 0.11 & 0.10 & 0.10 & 0.09 & 0.11 \\
\hline $\begin{array}{l}\text { Share of credit relations with } \\
\text { mutual banks }\end{array}$ & 0.05 & 0.06 & 0.05 & 0.05 & 0.05 & 0.07 & 0.07 & 0.08 & 0.06 \\
\hline $\begin{array}{l}\text { Share of credit relations with banks } \\
\text { involved in M\&As; HP: } D_{M A}=1\end{array}$ & 0.74 & 0.66 & 0.68 & 0.45 & 0.37 & 0.38 & 0.55 & 0.58 & 0.53 \\
\hline $\begin{array}{l}\text { Share of credit relations with banks } \\
\text { involved in M\&As and previously } \\
\text { jointly financing the same firm; HP: } \\
D_{\text {MAMULTI }}=1\end{array}$ & 0.05 & 0.06 & 0.04 & 0.02 & 0.00 & 0.06 & 0.11 & 0.13 & 0.05 \\
\hline Bank total assets (mln. $€$ ) & 31,005 & 35,575 & 54,735 & 62,646 & 50,402 & 55,010 & 66,518 & 71,803 & 54,156 \\
\hline Bank ROA (\%) & 1.06 & 1.15 & 1.01 & 0.97 & 0.78 & 0.81 & 0.88 & 1.05 & 0.95 \\
\hline Bank risk (bad loans/total loans) (\%) & 5.08 & 4.35 & 3.12 & 3.13 & 3.61 & 3.64 & 2.38 & 2.49 & 3.43 \\
\hline $\begin{array}{l}\text { Loan Herfindahl Index at province- } \\
\text { level (range } 0-10,000)\end{array}$ & 762.32 & 673.54 & 639.58 & 628.05 & 607.20 & 657.92 & 666.83 & 680.89 & 657.43 \\
\hline
\end{tabular}

(1) Descriptive statistics are obtained on the 712,005 obs. used in the baseline estimation based on the share calculated on the credit actually used by firms. (2) Firm leverage has been cleaned of outliers, censoring any observations lower than the 5th percentile and greater than the 95th percentile of the distribution.

is that the latter choice would have compelled us to consider pro-forma standard units for the whole period 1999-2009, thus providing a kind of snapshot of the banking groups in existence at the end of the period, ignoring all the available information on bank M\&As in the intermediate decade.

The estimation sample includes almost 20,000 companies, selected from the archives of the Centrale dei Bilanci (Company Accounts Data Service CADS), considering all the firms present for at least 6 of the 11 years between 1999 and 2009. The alternative was a closed sample over the whole period: this would have led to a very smaller sample (less than 8,000 units) and a bias towards companies with a high survival rate ${ }^{10}$

For each three-year period used in the estimates, we considered only the credit relationships of firms which were present in the database both

${ }^{10}$ Another alternative was to consider all the firms recorded in CADS for at least one year (over 44,000): in this way, however, there was a high risk of introducing too many erratic effects into the analysis. 
at time $t-3$ and time $t$. Overall, the dataset includes over 850,000 credit relationships (bank-firm-year). For more than 712,000 observations, the borrowing firms were actually using finance from their credit lines at a given reporting date. Moreover, we disposed of the whole set of controls at banklevel (drawn from the Bank of Italy's Supervisory Reports), at firm-level (built using CADS and ISTAT Data), and at credit relationship-level (taken from the Central Credit Register - CCR), and from the Bank of Italy's Census of Banks (Siotec Archive). In order to avoid effects of reverse causality in the estimates, such controls were included with appropriate time lags. The baseline equation estimated has the following form:

$$
\begin{gathered}
\operatorname{Share}_{(j, i, t)}=\alpha+\beta_{1} \operatorname{Share}_{(j, i, t-3)}+\beta_{2} D_{M A(j, t)}+\beta_{3} D_{M A M U L T I(j, t)}+\ldots \\
\ldots+\beta_{4} B_{(j, t-3)}+\beta_{5} X_{(i, t-1)}+\beta_{6} D_{P R O X(j, i, t)}+\beta_{7} H_{M K T(i, t)}+u_{j}+p_{i}+s_{i}+d_{t}+\varepsilon_{j, i, t}
\end{gathered}
$$

The share of bank $j$ on the overall bank credit used by firm $i$ at the end of year $t\left(\operatorname{Share}_{(j, i, t)}\right)$ is explained by the same proportion at the beginning of the period (identifying a possible path dependence) ${ }^{11}$ and by two dummies designed to capture the effects of mergers and acquisitions ${ }^{12}$ (see Section 3.3). The basic equation also includes controls for firm characteristics (vector $\left.X_{(i, t-1)}\right)$ and dummies for the firm's province $\left(p_{i}\right)$ and economic sector $\left(s_{s}\right)$, to take into account demand factors. The vector $B_{(j, t-3)}$ captures bank characteristics varying over time, while we included bank fixed effects $\left(u_{j}\right)$, to take into account other time-invariant factors related to the supply-side (e.g., bank organizational skills). In order to control for the competitiveness of the provincial markets in which firms operate, in all estimates we included the Herfindahl index of loan concentration $\left(H_{M K T(i, t)}\right)$. To account for the cyclical effect, we also added year dummies $\left(d_{t}\right)$ to our regressions. Finally, to capture the effects of the proximity of banks to firms, or the existence of economic agglomerations of firms, we included an indicator of territorial proximity between banks and firms $\left(D_{P R O X(j, i, t)}\right)$ and a dummy equal to 1 for district firms, the latter incorporated in the vector $X_{i}$.

Table A in the Statistical Appendix summarizes our variables and their expected signs; Tables 1 and 2 present the descriptive statistics on the esti-

\footnotetext{
${ }^{11}$ In order to take into account the dynamic nature of the model by introducing the lagged dependent variable, the baseline estimate was also carried out using GMM techniques à la Arellano-Bond. The main results on the M\&A dummies and on the other controls remain substantially unchanged.

12 The use of lagged control variables and of M\&A dummies is a consolidated methodology in the empirical literature to evaluate the effects of banking consolidation on credit availability and performance. By taking appropriate lagged data, we are able to tackle the potential endogeneity due to reverse causality problems. This is particularly true for our first regressor (the three-year lagged share of bank $j$ on the overall bank credit used by firm i), whose role is that to control for reverse causation, path dependence and to compare pro-forma data for each consolidated bank.
} 
mation sample, respectively pooled and presented by year. In the estimation period, each firm was borrowing, on average, from 10.5 banks in different relationships and each bank provided, on average, slightly less than 10 per cent of the firm's short-term outstanding credit. These values were slightly variable in the period 2002-09, but they are correlated (respectively, in a positive and a negative way) to the size of the firm. The average variation of the Share $_{j, i, t}$ in a three-year period is essentially zero $(-0.08$ percentage points), even if it is slightly greater for companies in the lower cluster by size. Around 56 per cent of the examined credit relationships were between firm and bank branches geographically close to each other, while 11 per cent concerned firms belonging to industrial districts (the latter value is obviously higher for SMEs). Finally, more than half of the credit relationships involved banks that participated in the consolidation process in the three previous years, but in only 5 per cent of the cases did M\&As involve two or more banks that at beginning of the period jointly financed the same company, and which therefore may have had incentives to reduce their relationship concentration.

\subsection{The Dependent Variable}

The share of each bank on the overall credit of firm $i$ was calculated using the individual data on bank-firm relationships drawn from the CCR. We considered only self-liquidating credits (the liquidity facilities granted using the commercial portfolio as collateral) and loans revocable on request (current account overdrafts or loans revocable by the bank on demand or at short notice). In fact, since a bank can not revoke a mortgage quickly, it is likely that only short-term credit lines will show high reactivity to bank consolidation, 13

Figure 2 and Table 3 show the average change, over three years, of the variable Share ${ }_{j, i, t}$ (calculated on the basis of credit actually used) for the whole estimation sample and for some sub-samples. Descriptively, they illustrate the trend towards a reduction of individual effort in financing single firms on the part of banks that have merged. Indeed, considering all banks, without distinguishing between those involved in M\&As or not, in a three-year horizon the variation of the average share of each intermediary in the financing of each firm is negligible. However, taking into account

\footnotetext{
${ }^{13}$ We have also carried out experiments based on total credit. The signs of the results are in line with those obtained only for short-term loans; as expected, however, the coefficients are slightly lower, confirming that in this case the effects of bank mergers on the dependent variable are weaker. In order to increase the robustness of the results, we made the regressions keeping the observations between the 5 th and the 95 th percentile of the distribution of the difference between $\operatorname{Share}_{(j, i, t-3)}$ and $\operatorname{Share}_{(j, i, t)}$. This choice was motivated by the opportunity to eliminate cases in which a change of the share is very large due to outliers, and not related to the reorganization of the bank-firm relationships post-M\&A. We also made checks using weaker criteria for the cleaning up of the database: also in this case, the main results were substantially confirmed.
} 
Figure 2 - The Average Change, over a Three-Year Period, of the Percentage Share of the Overall Short-Term Credit to a Firm Provided by Each Lender

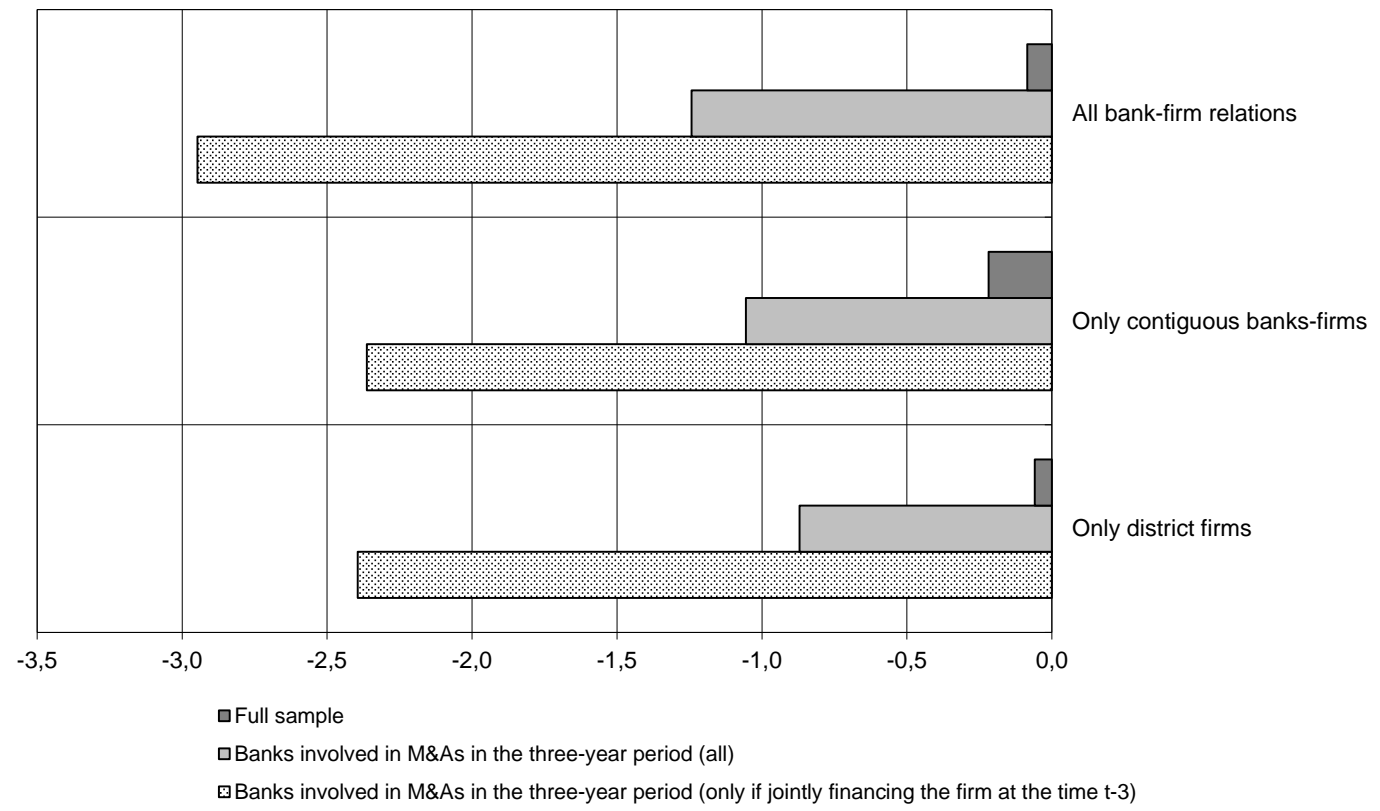

only the banks that during the three years have participated at least one aggregation, there is an average unconditional reduction of more than 1.2 percentage points in their share of exposure. Still restricting the analysis to only those cases in which the consolidation has involved at least two of the banks that jointly financed the same customer at the same time (the case we are interested in), the reduction is more significant (almost 3 percentage points).

Figure 2 and Table 3 also show that for banks characterized by spatial contiguity with the borrowing company (the cases in which at least one branch of the lending intermediary operates in the same municipality of the firm), as well as for district firms, the average reduction in the postaggregation share is smaller. This suggests that bank-firm relationships facilitated by geographical proximity, which enhances soft information and reduces its cost, or by firms' inclusion in spatial agglomerations, may be more resilient to shocks such as those resulting from the consolidation of lenders (Sapienza, 2002) 14

\footnotetext{
${ }^{14}$ The paper by Sapienza finds rationing effects differentiated between M\&As involving intermediaries operating in the same market and those concerning distant intermediaries (i.e. transactions "in the market" and "out of the market"). This suggests that the proximity of the customer to one or more of the banks involved in consolidations is a variable that should be carefully analysed.
} 
Table 3 - Average Change Over a Three-Year Period of the Share of Each Financing Bank on the Total Bank Loans of Borrowing Firm (1) (percentage points)

\begin{tabular}{cccc}
\hline & $\begin{array}{c}\text { All bank-firm } \\
\text { credit relations }\end{array}$ & $\begin{array}{c}\text { Only those relations with } \\
\text { bank-firm geographical } \\
\text { proximity (2) }\end{array}$ & $\begin{array}{c}\text { Only those credit relations with } \\
\text { district firms (3) }\end{array}$ \\
\hline Whole sample & $-\mathbf{0 . 0 8 5}$ & $-\mathbf{0 . 2 1 8}$ & $-\mathbf{0 . 0 5 9}$ \\
of which: small banks (4) & 0.145 & 0.001 & 0.092 \\
large banks & -0.820 & -0.921 & -0.564 \\
of which: small firms (5) & -0.084 & -0.244 & -0.061 \\
large firms & -0.086 & -0.146 & -0.050 \\
Banks involved in M\&As & $-\mathbf{1 . 2 4 3}$ & -1.055 & $-\mathbf{0 . 8 7 0}$ \\
of which: small banks (4) & -1.170 & -1.166 & -0.861 \\
large banks & -1.372 & -0.860 & -0.889 \\
of which: small firms (5) & -1.341 & -1.155 & -0.918 \\
large firms & -0.943 & -0.764 & -0.621 \\
Banks involved in M\&As and jointly & $-\mathbf{2 . 9 4 7}$ & $-\mathbf{2 . 3 6 3}$ & $-\mathbf{2 . 3 9 4}$ \\
financing the same firm at time $\boldsymbol{t}-\mathbf{3}$ & -2.386 & -2.169 & -2.121 \\
of which: small banks (4) & -3.157 & -2.433 & -2.533 \\
large banks & -3.081 & -2.543 & -2.224 \\
of which: small firms (5) & -2.700 & -2.039 & -2.994 \\
\hline large firms & & & \\
\hline \hline
\end{tabular}

(1) Descriptive statistics are obtained on the 712,005 obs. used in the baseline estimation based on the share calculated on the credit actually used by firms. (2) Only those obs. with the dummy $D_{P R O X}$ equal to 1. (3) Only those obs. with the dummy $D_{D I S T}$ equal to 1. (4) We consider small banks those with total assets lower than the third quartile of the total assets' distribution; and large banks the others. (5) We consider small firms those with total sales lower than the third quartile of the total sales' distribution; large firms the others.

\subsection{Bank MEAs}

The two dummies for bank involvement in the aggregation process, on which this paper is focused, are based on the Bank of Italy's Census of banks (for mergers) and on the Bank of Italy's Banking Group Register (for acquisitions).

The first dummy, $D_{M A}$, is equal to 1 for all banks involved in at least one consolidation during each three-year period under examination. The second, $D_{M A M U L T I}$, indicates two simultaneous conditions: (1) bank $j$ has participated in at least one aggregation in the three-year period, and (2) bank $j$ was not the only lending bank, among those which have merged, to finance firm $i$ at the end of year $t-3 \sqrt{15}$ This is really the condition in which, according to our a priori, the bank could have an incentive to downsize the individual credit share in the financing of the same firm, if the benefit stemming from diversification is perceived to be greater than the cost associated with the loss of information. For this reason, $D_{M A M U L T I}$ represents the main variable of interest of our analysis.

\footnotetext{
${ }^{15}$ For a more analytical explanation about the design of these dummies, see the Methodological Appendix.
} 


\subsection{Controlling for Bank and Firm Characteristics}

The bank controls, represented by the vector $B_{(j, t-3)}$, take into account the size, profitability and credit risk of each intermediary (see Table A in the Appendix for the analytical definitions). To avoid reverse causality problems, these variables are measured at the end of year $t-3$, which is the beginning of each three-year period examined in the econometric exercise. We also use the provincial Herfindahl index, calculated on the basis of loans at province level, as a control for the degree of concentration of the local credit markets where firms are headquartered.

Vector $\mathrm{X}_{i, t-1}$ introduces firm controls: there are indicators of size, profitability, leverage and financial fragility. These variables are measured with a time lag, to avoid problems related to reverse causation. ${ }^{16}$ We also added a synthetic indicator of ex-ante economic and financial riskiness of the firm, namely the CADS Z-score. This index ranges from 1 (essentially, firms with no risk) to 9 (highly financially distressed firms). Moreover, there are, in some specifications, controls for firm-specific characteristics that, according to the literature, could have an impact on the sensitivity of credit relationships to banks' M\&As: that is, localization in the South, high-tech sectors (i.e., there is probably a higher need for lenders to handle soft information), or belonging to an industrial district. Finally, there are dummy variables which take into account the province of the firm's headquarters and its economic sector (agriculture and mining, industry, construction and services): these factors could in fact be related to the credit demand-side.

\subsection{Specific Features of the Credit Relationship: Geographi- cal Proximity and Agglomerations of Firms}

At relationship-level we introduced a control for the distance between the bank's branch network and the borrowing firm $\left(D_{P R O X(j, i, t)}\right)$. It can be argued that, when the bank-firm relationship is facilitated by geographical proximity (Cerqueiro et al., 2009), post-M\&A the bank has less incentive to reduce its commitment to financing a firm. ${ }^{17}$ The dummy $D_{P R O X}$ is equal to 1 if the bank has at least one branch in the municipality in which the firm is headquartered.

Finally, we defined an indicator for district firms $\left(D_{D I S T(i)}\right)$, merging the information about firm location and the map of industrial districts provided

${ }^{16}$ The lending banks, in their creditworthiness assessments, usually take into account the firm's current situation and outlook rather than its past performance. So, a three-year lag could lead to an incorrect representation of the real economic and financial situation of the firm at the time of bank's screening. We therefore measured these variables with a lag of only one year $(t-1)$.

${ }^{17}$ The increasing distance between banks and firms emphasizes information asymmetries; so, there is a greater probability of credit rationing for customers further away from bank branches (Hauswald and Marquez, 2006). 
by Sforzi-Istat (2001). This is a dummy that is equal to 1 if the firm is located in a municipality identified as an industrial district, and if it belongs to the specific economic sector of district specialization.

The geographical proximity of banks to firms and the condition of a firm belonging to a district are strongly relevant to the degree of concentration of credit relationships. Actually, as shown in Figure 2 (see Section 3.2), these features attenuate the decline of bank's commitment to overall funding to a firm, related to consolidated intermediaries. This is true for all the conditions in which banks can be involved in the aggregation process and suggests that for a firm, the geographical closeness to a bank branch and the location in a district area could grant a greater protection against exogenous shocks, such as bank M\&As.

\section{Results}

\subsection{Bank-Firm Credit Relationships and the Effects of Bank- ing Consolidations}

The empirical analysis was carried out estimating linear regression models with bank fixed effects to better control for time-invariant variables at bank level, such as organizational skills, management quality, different lending techniques, and so on. In order to obtain robust results, and account for the error correlation within groups of firms financed by different banks in multiple relationships, standard errors are corrected for clusters at firm level.

The share of credit provided by each bank on the overall credit of each firm in our sample at the end of each three-year period (the dependent variable) was measured either by the credit actually used (utilizzato) by the client or by the credit granted by the bank (accordato), as the maximum amount available for the financial needs of the firm. For the short-term lines of credit, which we focus on, the difference between credit used and granted can be significant. Studying the changes post-M\&As in the share of bank credit in each banking relationship from the point of view of the credit granted can be useful for at least two reasons. First, this configuration can be a robustness check for results obtained by analysing the credit actually used by each firm. Second, the credit granted represents the maximum availability of bank finance for the client: so the econometric exercise conducted on both configurations of bank lending can help take into account the role of demand and supply factors in causing the changes in the relationship mix after banking consolidation. ${ }^{18}$ In order to investigate more carefully

${ }^{18}$ It is important to notice that, generally, the credit granted (accordato) is an imperfect proxy for the credit supply-side. The level of credit granted to each client is determined by a negotiation process between lender and borrower, and thus it depends on the interaction 
demand factors that may affect the concentration degree of the single bankfirm relationships, in all estimates we have included dummy variables at province-level, calculated on the basis of the localization of firms' headquarters, and sector dummy variables, taking into account the economic macro-sector to which firms belong, distinguishing between agriculture and mining, manufacturing, construction and service sectors. 19

Table 4 reports results on our baseline specification. Firstly, analysing the credit actually used by firms (column I), as expected, the bank share at time $t$ is positively correlated to the comparable pro-forma share at the beginning of each three-year period. Its estimated parameter (equal to 0.73) suggests that share $t$ depends mainly on the starting point at $t-3$. The evidence that more concentrated relationships in the past tend to preserve this characteristic over time seems to be related to the incentive that main banks usually have to maintain a strategic approach in relationship lending, in order to preserve their advantage in terms of acquiring soft information. However, since the coefficient is less than 1, the share over time tends to slightly decrease the higher is the past degree of credit concentration, enhancing diversification strategies.

The involvement of banks in M\&As, as measured by the dummy $D_{M A}$, does not have a statistically significant effect per se on the degree of credit concentration. What really matters for the concentration of credit relationships is the case in which the consolidation process involves two or more banks that were financing the same firm at the beginning of each three-year period. Indeed, in this hypothesis the confluence in the same group, as a result of M\&As, generates - other things being equal - an incentive for consolidated banks to diversify the overall position towards the client, in order to avoid an excessive credit concentration and a high counterparty risk. As a matter of fact, the dummy $D_{M A M U L T I}-$ which aims to take into account precisely this multiple bank consolidation hypothesis - has a negative and significant estimated parameter. ${ }^{20}$ However, in economic terms, the impact of multiple bank M\&As on credit concentration is limited: the estimated parameter suggests a decrease in the consolidated banks' credit

\footnotetext{
between credit supply and loan demand. In our particular case, however, this approximation may be acceptable. What we investigate is the post M\&A reduction of the share of credit granted by the bank to a specific borrower; since - at least in the period under analysis - in Italy there were very few fees for credit granted, it is very unlikely that this decrease depends on a customer's request. It is more plausible that the client would reduce the credit actually used (utilizzato), in order to diversify his/her credit relationships.

19 "Agriculture and mining" is used as the basic sector in the model. In unreported estimates, we controlled for sector dummies based on 2-digit classifications (about 20 sectors) and our main results do not change.

${ }^{20}$ In unreported estimates we also used annual $D_{M A M U L T I}$ dummy variables to check the robustness of our findings, and to better capture the dynamic aspect of the investigated phenomenon. The main results of the analysis hold, but we find that the main effects on the dependent variable emerge more than one year after consolidation events and strengthen gradually over time.
} 
Table 4 - Baseline Estimation

\begin{tabular}{|c|c|c|}
\hline & Credit actually used (I) & Credit granted (II) \\
\hline Share $_{\mathrm{j}, \mathrm{i}, \mathrm{t}-3}$ & $\begin{array}{c}0.730 * * * \\
{[0.002]}\end{array}$ & $\begin{array}{c}0.817^{* * *} \\
{[0.002]}\end{array}$ \\
\hline $\mathrm{D}_{\mathrm{MA}}$ & $\begin{array}{c}-0.053 \\
{[0.046]}\end{array}$ & $\begin{array}{c}0.045 \\
{[0.032]}\end{array}$ \\
\hline D Mamulti & $\begin{array}{c}-0.540 * * * \\
{[0.076]}\end{array}$ & $\begin{array}{c}-0.867^{* * *} \\
{[0.052]}\end{array}$ \\
\hline DPROX & $\begin{array}{c}0.361 * * * \\
{[0.029]}\end{array}$ & $\begin{array}{c}0.279 * * * \\
{[0.022]}\end{array}$ \\
\hline Firm size & $\begin{array}{c}-0.434^{* * *} \\
{[0.013]}\end{array}$ & $\begin{array}{c}-0.353^{* * *} \\
{[0.010]}\end{array}$ \\
\hline Firm ROA & $\begin{array}{c}-0.012 * * * \\
{[0.003]}\end{array}$ & $\begin{array}{c}0.002 \\
{[0.002]}\end{array}$ \\
\hline Firm leverage & $\begin{array}{l}-0.005^{*} \\
{[0.002]}\end{array}$ & $\begin{array}{c}0.005 * * * \\
{[0.002]}\end{array}$ \\
\hline Firm rating & $\begin{array}{c}0.069 * * * \\
{[0.010]}\end{array}$ & $\begin{array}{c}-0.198 * * * \\
{[0.007]}\end{array}$ \\
\hline Local credit market concentration & $\begin{array}{l}0.000^{*} \\
{[0.000]}\end{array}$ & $\begin{array}{c}0.000 * * * \\
{[0.000]}\end{array}$ \\
\hline Bank size & $\begin{array}{c}-2.768^{* * *} \\
{[0.086]}\end{array}$ & $\begin{array}{c}-2.801 * * * \\
{[0.070]}\end{array}$ \\
\hline Bank ROA & $\begin{array}{c}0.307 * * * \\
{[0.024]}\end{array}$ & $\begin{array}{c}0.274 * * * \\
{[0.017]}\end{array}$ \\
\hline Bank risk & $\begin{array}{c}0.043^{* * *} \\
{[0.009]}\end{array}$ & $\begin{array}{c}0.054^{* * *} \\
{[0.007]}\end{array}$ \\
\hline Dummy Manufacturing sector & $\begin{array}{c}-0.143 \\
{[0.127]}\end{array}$ & $\begin{array}{c}-0.141 \\
{[0.097]}\end{array}$ \\
\hline Dummy Construction sector & $\begin{array}{c}-0.467^{* * *} \\
{[0.136]}\end{array}$ & $\begin{array}{c}-0.456^{* * *} \\
{[0.103]}\end{array}$ \\
\hline Dummy Service sector & $\begin{array}{c}0.039 \\
{[0.129]}\end{array}$ & $\begin{array}{l}-0.122 \\
{[0.098]}\end{array}$ \\
\hline Dummy firm province & YES & YES \\
\hline Bank fixed effects & YES & YES \\
\hline Dummy Year & YES & YES \\
\hline Constant & $\begin{array}{c}71.321^{* * *} \\
{[2.040]}\end{array}$ & $\begin{array}{c}70.743^{* * *} \\
{[1.654]}\end{array}$ \\
\hline N. obs & 712,005 & 782,253 \\
\hline Adjusted R-squared & 0.59 & 0.74 \\
\hline
\end{tabular}

Dependent variable: Percentage share of credit provided by bank $j$ on the overall short-term loans of firm $i$ at time t. Linear regressions with bank fixed effects; robust standard errors (in brackets) are clustered at firm level. Symbols ${ }^{*},{ }^{* *},{ }^{* \star *}$, respectively, indicate significance level at $10 \%, 5 \%$, and $1 \%$. 
share of around 0.5 percentage points relative to other banks. Having in mind the trade-off between strategic approach to relationship lending and costs of firms' hold-up and liquidity risk, this downward trend post-M\&A of bank credit exposures could support the idea that diversification scope (for both bank and borrower) slightly prevails over that of preserving soft information collected by face-to-face lending relationships.

The evidence outlined above is confirmed by adopting the configuration that measures the share of credit in terms of credit granted (Table 4, column II). In this case, however, the estimated decrease is moderately greater: the parameter of $D_{M A M U L T I}$ is equal to -0.87 percentage points (compared to -0.54 for the credit used); this could imply that the decrease in the credit share, provided by consolidated banks which jointly financed the same firm, seems to be related to the prominent role of diversification strategies on the supply-side.

Interesting insights also arise from the other control variables related to firm characteristics or to credit relationship features. The dummy $D_{P R O X}$ takes into account the geographical proximity between banks and firms, based on the assumption that the proximity of the two parties has an effect on the improvement of bank-customer relationships, cutting the costs of collecting soft information and reducing the information asymmetries. From our baseline estimate it emerges that the credit share of financing banks geographically closer to the borrowing firm is greater than that of the other lenders (on average, about one third of a percentage point).

Concerning borrower characteristics, we find that credit relationships are more concentrated towards smaller firms, identified by considering the (logarithm of) sales, mainly with only one or in any case a small number of lenders. ${ }^{21}$ The size effect dominates compared with firm leverage and profitability, the parameters of which, even if significant, appear to be close to zero. To take into account more carefully the impact of the borrowing firm's financial risk on the "strength" of the credit relationship between the two parties, we also control for the Z-score drawn from CADS; this indicator increases the higher the firm's financial riskiness. The estimated coefficient of this variable, considering the share calculated by the credit actually used by the client, is positive and significant, suggesting that - other things being equal - the borrowers most exposed to financial risks are those that appear to have more concentrated credit relationships. On the one hand, it is likely

${ }^{21}$ To investigate the differential effect of firm size on the degree of concentration of credit relations after bank M\&As, we have included in the estimation a dummy variable $\left(D_{S M A L L F I R M}\right)$ that is equal to 1 for firms up to 60 employees (the median value in our sample), and zero otherwise; then, this new dummy is interacted with the dummy $D_{M A M U L T I}$. Results, not reported here for brevity, suggest that using a dichotomous measure of firm size, small firms have more concentrated bank credit relationships than larger enterprises, but in the case of relationships with financing banks involved in mergers, there are no differential effects for small firms on the impact of the consolidation process on credit concentration relative to the effect recorded on the whole sample. 
that riskier firms had fewer alternative financing channels to those already used. On the other hand, most exclusive and long-lasting relationships with banks less exposed to information asymmetries, due to their advantage in gathering soft information, seem to be more appropriate in restructuring companies in financial distress (Micucci and Rossi, 2010). However, in the model based on the credit granted, the estimated coefficient on the Z-score is negative and significant: in other words, firms with higher financial riskiness (a higher rating) induce banks to react by reducing their willingness to extend the amount of credit availability for the customer, according to the 'flight-to-quality' strategy; yet, it is more likely that the actual lenders tend to restructure the debt already incurred by the firm, if they are more involved in financing it.

With regard to the bank level variables, the larger banks show a more significant reduction of their share on the total credit of the borrowing firm, consistent with the loss of market share recorded in the last decade for medium-sized and large intermediaries (Bonaccorsi di Patti et al., 2005). Higher profitability, a proxy of bank health, allows banks to expand their commitment towards financed firms. A similar effect stems from the increasing bank portfolio risk, measured as the ratio between non-performing loans and total loans, even if the economic impact is still quantitatively small.

Finally, the structural characteristics of the local credit markets where firms are headquartered, approximated by the Herfindahl index on loans at province-level, have a positive and statistically significant effect on the credit concentration of each relationship, but the effect is in economic terms close to zero 22

Not distinguishing the effects of mergers from those of acquisitions could hide different bank behaviour after the two types of event. In particular, it seems likely that changes in credit relationship concentration are more severe after a merger than after an acquisition, since the former creates a wider and more complex organizational integration among the involved intermediaries. Results presented in Table 5 disentangle the effects of mergers and acquisitions and suggest that there are statistically significant differences in credit concentration stemming from the two events, but these differences are small. Indeed, the estimated parameter for the dummy $D_{M A M U L T I}$ is higher considering only mergers than in the case of acquisitions: respectively, -0.59 versus -0.49 percentage points, for the share measured in terms of credit actually used, -0.95 versus -0.82 , for the share calculated on credit granted. These differences are significant, but not particularly large. Therefore, different organizational choices in the banking consolidation process

\footnotetext{
${ }^{22}$ The controls for demand factors, using dummies at province and sector level, show heterogeneity of relationships in local markets, and suggest that the relationships are usually less concentrated for construction firms, an industry characterized by smaller and more opaque firms than in other sectors.
} 


\begin{tabular}{|c|c|c|c|c|}
\hline & \multicolumn{2}{|c|}{ Mergers } & \multicolumn{2}{|c|}{ Acquisitions } \\
\hline & $\begin{array}{l}\text { Credit actually used } \\
\text { (I) }\end{array}$ & $\begin{array}{l}\text { Credit granted } \\
\text { (II) }\end{array}$ & $\begin{array}{l}\text { Credit actually used } \\
\text { (III) }\end{array}$ & $\begin{array}{l}\text { Credit granted } \\
\text { (IV) }\end{array}$ \\
\hline Share $_{\mathrm{j}, \mathrm{i}, \mathrm{t}-3}$ & $\begin{array}{c}0.730 * * * \\
{[0.002]}\end{array}$ & $\begin{array}{c}0.817^{* * *} \\
{[0.002]}\end{array}$ & $\begin{array}{c}0.730 * * * \\
{[0.002]}\end{array}$ & $\begin{array}{c}0.817^{* * *} \\
{[0.002]}\end{array}$ \\
\hline $\mathrm{D}_{\mathrm{MA}}$ & $\begin{array}{c}0.062 \\
{[0.042]}\end{array}$ & $\begin{array}{c}0.173 * * * \\
{[0.028]}\end{array}$ & $\begin{array}{c}0.293 * * * \\
{[0.044]}\end{array}$ & $\begin{array}{c}0.291^{* * *} \\
{[0.029]}\end{array}$ \\
\hline Dмamulti & $\begin{array}{c}-0.592 * * * \\
{[0.080]}\end{array}$ & $\begin{array}{c}-0.951^{* * *} \\
{[0.054]}\end{array}$ & $\begin{array}{c}-0.487 * * * \\
{[0.078]}\end{array}$ & $\begin{array}{c}-0.823 * * * \\
{[0.053]}\end{array}$ \\
\hline$D_{\text {PROX }}$ & $\begin{array}{c}0.362 * * * \\
{[0.029]}\end{array}$ & $\begin{array}{c}0.282 * * * \\
{[0.022]}\end{array}$ & $\begin{array}{c}0.364 * * * \\
{[0.029]}\end{array}$ & $\begin{array}{c}0.281 * * * \\
{[0.022]}\end{array}$ \\
\hline Firm size & $\begin{array}{c}-0.434 * * * \\
{[0.013]}\end{array}$ & $\begin{array}{c}-0.353^{* * *} \\
{[0.010]}\end{array}$ & $\begin{array}{c}-0.434^{* * *} \\
{[0.013]}\end{array}$ & $\begin{array}{c}-0.354 * * * \\
{[0.010]}\end{array}$ \\
\hline Firm ROA & $\begin{array}{c}-0.012 * * * \\
{[0.003]}\end{array}$ & $\begin{array}{c}0.002 \\
{[0.002]}\end{array}$ & $\begin{array}{c}-0.012 * * * \\
{[0.003]}\end{array}$ & $\begin{array}{c}0.002 \\
{[0.002]}\end{array}$ \\
\hline Firm leverage & $\begin{array}{l}-0.004^{*} \\
{[0.002]}\end{array}$ & $\begin{array}{c}0.005 * * * \\
{[0.002]}\end{array}$ & $\begin{array}{l}-0.004^{*} \\
{[0.002]}\end{array}$ & $\begin{array}{c}0.005 * * * \\
{[0.002]}\end{array}$ \\
\hline Firm rating & $\begin{array}{c}0.069 * * * \\
{[0.010]}\end{array}$ & $\begin{array}{c}-0.198 * * * \\
{[0.007]}\end{array}$ & $\begin{array}{c}0.068^{* * *} \\
{[0.010]}\end{array}$ & $\begin{array}{c}-0.198 * * * \\
{[0.007]}\end{array}$ \\
\hline Local credit market concentration & $\begin{array}{c}0.000 \\
{[0.000]}\end{array}$ & $\begin{array}{c}0.000 * * * \\
{[0.000]}\end{array}$ & $\begin{array}{l}0.000^{*} \\
{[0.000]}\end{array}$ & $\begin{array}{c}0.000 * * * \\
{[0.000]}\end{array}$ \\
\hline Bank size & $\begin{array}{c}-2.751^{* * *} \\
{[0.087]}\end{array}$ & $\begin{array}{c}-2.761 * * * \\
{[0.070]}\end{array}$ & $\begin{array}{c}-2.757^{* * *} \\
{[0.086]}\end{array}$ & $\begin{array}{c}-2.796 * * * \\
{[0.070]}\end{array}$ \\
\hline Bank ROA & $\begin{array}{c}0.308 * * * \\
{[0.024]}\end{array}$ & $\begin{array}{c}0.280 * * * \\
{[0.017]}\end{array}$ & $\begin{array}{c}0.298 * * * \\
{[0.024]}\end{array}$ & $\begin{array}{c}0.270 * * * \\
{[0.017]}\end{array}$ \\
\hline Bank risk & $\begin{array}{c}0.045 * * * \\
{[0.009]}\end{array}$ & $\begin{array}{c}0.056 * * * \\
{[0.007]}\end{array}$ & $\begin{array}{c}0.050 * * * \\
{[0.009]}\end{array}$ & $\begin{array}{c}0.059 * * * \\
{[0.007]}\end{array}$ \\
\hline Dummy Manufacturing sector & $\begin{array}{l}-0.142 \\
{[0.127]}\end{array}$ & $\begin{array}{l}-0.140 \\
{[0.097]}\end{array}$ & $\begin{array}{l}-0.142 \\
{[0.127]}\end{array}$ & $\begin{array}{l}-0.140 \\
{[0.097]}\end{array}$ \\
\hline Dummy Construction sector & $\begin{array}{c}-0.467 * * * \\
{[0.136]}\end{array}$ & $\begin{array}{c}-0.456 * * * \\
{[0.103]}\end{array}$ & $\begin{array}{c}-0.468 * * * \\
{[0.136]}\end{array}$ & $\begin{array}{c}-0.456 * * * \\
{[0.103]}\end{array}$ \\
\hline Dummy Service sector & $\begin{array}{c}0.039 \\
{[0.129]}\end{array}$ & $\begin{array}{l}-0.122 \\
{[0.098]}\end{array}$ & $\begin{array}{c}0.040 \\
{[0.129]}\end{array}$ & $\begin{array}{l}-0.120 \\
{[0.098]}\end{array}$ \\
\hline Dummy firm province & YES & YES & YES & YES \\
\hline Bank fixed effects & YES & YES & YES & YES \\
\hline Dummy Year & YES & YES & YES & YES \\
\hline Constant & $\begin{array}{c}70.855^{* * *} \\
{[2.057]}\end{array}$ & $\begin{array}{c}69.744^{* * *} \\
{[1.667]}\end{array}$ & $\begin{array}{c}70.799 * * * \\
{[2.042]}\end{array}$ & $\begin{array}{c}70.440 * * * \\
{[1.654]}\end{array}$ \\
\hline N. obs & 712,005 & 782,253 & 712,005 & 782,253 \\
\hline Adjusted R-squared & 0.59 & 0.74 & 0.59 & 0.74 \\
\hline
\end{tabular}

Dependent variable: Percentage share of credit provided by bank $j$ on the overall short-term loans of firm $i$ at time t. Linear regressions with bank fixed effects; robust standard errors (in brackets) are clustered at firm level. Symbols ${ }^{*},{ }^{* *},{ }^{* \star *}$, respectively, indicate significance level at $10 \%, 5 \%$, and $1 \%$.

have a limited effect on changes in credit relationship concentration.

\subsection{Some Different Effects at Firm Level}

In order to analyse differential effects of banking consolidation related to specific firm characteristics, we have included in our baseline specification further interaction variables between the dummy $D_{M A M U L T I}$, accounting for multiple M\&As, and other firm features.

The role of negative externalities in some areas of the country - partic- 
ularly in the southern Italian regions - is an issue that has already been investigated in the literature, with the aim of studying differences in credit availability towards firms headquartered in that area, due to a higher level of non-idiosyncratic risk perceived by lenders. ${ }^{23}$ It is therefore interesting to analyse whether firms headquartered in the South experienced, as expected, a more severe impact on their credit concentration than elsewhere, after bank consolidation involving two or more financing banks.

The findings are presented in Table 6, using as dependent variable the bank credit share measured both in terms of credit actually used and granted (respectively, columns I and II). In order to perform this exercise we added to our baseline specification a dummy $D_{S O U T H}$, which is equal to 1 for all firms headquartered in the South of Italy. This dummy is not per se significant, since spatial heterogeneity is already absorbed by the province dummies included in the estimation; however, the most interesting evidence comes from the variable constructed as an interaction between $D_{\text {SOUTH }}$ and $D_{M A M U L T I}$ : the interaction term returns a negative and significant parameter $(-1.27$ and -0.70 , respectively according to the credit actually used or simply to that granted), signalling that southern firms really face, on average, a slightly more substantial decline in the share of credit jointly provided by consolidated financing banks.

Another important feature to study, for its possible links with information asymmetry and the degree of concentration of bank-firm credit relationships, is lending to innovative firms, belonging to high-tech sectors, compared with more traditional ones. Firstly, high-tech firms have a high share of intangible assets, and secondly their industrial projects are more risky and difficult to assess for lenders (Magri, 2009). Both these features suggest that the use of soft information is particularly relevant for innovative firms, and that shocks stemming from bank M\&As involving their financing banks may have stronger effects on credit relationships than in the case of firms belonging to medium-low tech sectors.

Columns III and IV of Table 6 analyse this hypothesis, adding to the model a dummy $D_{H I T E C H}$, which is equal to 1 for all firms operating in high technology sectors according to the OECD classification. ${ }^{24}$ Considering bank share in terms of the credit used by each firm, the estimated parameter on the dummy high-tech is negative and significant; this suggests that usually innovative firms tend to have - other things being equal - multiple and more diversified credit relationships than other firms, presumably because of their higher risk and volatility. However, the interaction between $D_{H I T E C H}$ and $D_{M A M U L T I}$ does not show statistically significant effects: this implies that there are no relevant differences in the downward trend of credit concentration in bank-firm relationships post-bank-M\&As, in the financing of high-tech firms.

\footnotetext{
23 See Bonaccorsi di Patti (2009).

${ }^{24}$ See OECD (2003).
} 
Table 6 - Different Effects by Firm Characteristics

\begin{tabular}{|c|c|c|c|c|c|c|}
\hline & \multicolumn{2}{|c|}{ Southern firms } & \multicolumn{2}{|c|}{ High tech firms } & \multicolumn{2}{|c|}{ Firm rating } \\
\hline & $\begin{array}{c}\text { Credit actually } \\
\text { used (I) }\end{array}$ & $\begin{array}{c}\text { Credit } \\
\text { granted (II) }\end{array}$ & $\begin{array}{c}\text { Credit actually } \\
\text { used (III) }\end{array}$ & $\begin{array}{c}\text { Credit } \\
\text { granted (IV) }\end{array}$ & $\begin{array}{c}\text { Credit actually } \\
\text { used (V) }\end{array}$ & $\begin{array}{c}\text { Credit } \\
\text { granted (VI) }\end{array}$ \\
\hline \multirow[t]{2}{*}{ Share $_{\mathrm{j}, \mathrm{i}, \mathrm{t}-3}$} & $0.730 * * *$ & $0.817 * * *$ & $0.730 * * *$ & $0.817 * * *$ & $0.730 * * *$ & $0.817 * * *$ \\
\hline & [0.002] & [0.002] & [0.002] & [0.002] & [0.002] & [0.002] \\
\hline \multirow[t]{2}{*}{$D_{M A}$} & -0.053 & 0.045 & -0.053 & 0.045 & -0.053 & 0.046 \\
\hline & {$[0.046]$} & {$[0.031]$} & [0.046] & [0.032] & {$[0.046]$} & {$[0.032]$} \\
\hline \multirow[t]{2}{*}{ DMAMULTI } & $-0.380 * * *$ & $-0.785 * * *$ & $-0.550 * * *$ & $-0.882 * * *$ & $1.234^{* * *}$ & $0.323^{* *}$ \\
\hline & [0.079] & [0.054] & [0.077] & [0.052] & [0.247] & [0.150] \\
\hline \multirow[t]{2}{*}{$D_{\text {PROX }}$} & $0.356 * * *$ & $0.277^{* * *}$ & $0.364 * * *$ & $0.280 * * *$ & $0.362^{* * *}$ & $0.281^{* * *}$ \\
\hline & [0.029] & [0.022] & [0.029] & [0.022] & [0.029] & [0.022] \\
\hline \multirow[t]{2}{*}{ Firm size } & $-0.434 * * *$ & $-0.353 * * *$ & $-0.434 * * *$ & $-0.353 * * *$ & $-0.434 * * *$ & $-0.353 * * *$ \\
\hline & [0.013] & [0.010] & [0.013] & [0.010] & [0.013] & [0.010] \\
\hline \multirow[t]{2}{*}{ Firm ROA } & $-0.012 * * *$ & 0.002 & $-0.012 * * *$ & 0.002 & $-0.012 * * *$ & 0.002 \\
\hline & [0.003] & [0.002] & [0.003] & {$[0.002]$} & [0.003] & {$[0.002]$} \\
\hline \multirow[t]{2}{*}{ Firm leverage } & $-0.005^{*}$ & $0.005^{* * *}$ & $-0.005^{* *}$ & $0.005^{* *}$ & $-0.005^{* *}$ & $0.004 * *$ \\
\hline & [0.002] & [0.002] & [0.002] & [0.002] & [0.002] & [0.002] \\
\hline \multirow[t]{2}{*}{ Firm rating } & $0.068 * * *$ & $-0.198 * * *$ & $0.070 * * *$ & $-0.198 * * *$ & $0.088 * * *$ & $-0.184 * * *$ \\
\hline & [0.010] & [0.007] & [0.010] & [0.007] & [0.010] & [0.007] \\
\hline \multirow[t]{2}{*}{ Firm rating $*$ D MAMULTI } & & & & & $-0.345^{* * *}$ & $-0.243^{* * *}$ \\
\hline & & & & & [0.044] & [0.028] \\
\hline \multirow[t]{2}{*}{ D SOUTH $_{\text {SO }}$} & -0.133 & -0.030 & & & & \\
\hline & [0.194] & [0.136] & & & & \\
\hline \multirow[t]{2}{*}{ 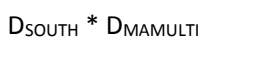 } & $-1.271 * * *$ & $-0.699 * * *$ & & & & \\
\hline & [0.221] & [0.156] & & & & \\
\hline \multirow[t]{2}{*}{$D_{\text {HITECH }}$} & & & $-0.377^{* * *}$ & -0.091 & & \\
\hline & & & [0.081] & {$[0.060]$} & & \\
\hline \multirow[t]{2}{*}{$\mathrm{D}_{\text {HITECH }} * \mathrm{D}_{\text {MAMULTI }}$} & & & 0.288 & $0.420 *$ & & \\
\hline & & & [0.369] & {$[0.241]$} & & \\
\hline \multirow{2}{*}{$\begin{array}{l}\text { Local credit market } \\
\text { concentration }\end{array}$} & 0.000 & $0.000 * * *$ & $0.000^{*}$ & $0.000 * * *$ & 0.000 & $0.000 * * *$ \\
\hline & [0.000] & [0.000] & [0.000] & [0.000] & [0.000] & [0.000] \\
\hline \multirow[t]{2}{*}{ Bank size } & $-2.766 * * *$ & $-2.800 * * *$ & $-2.769 * * *$ & $-2.801 * * *$ & $-2.767 * * *$ & $-2.799 * * *$ \\
\hline & [0.086] & [0.070] & [0.086] & [0.070] & [0.086] & [0.070] \\
\hline \multirow[t]{2}{*}{ Bank ROA } & $0.308 * * *$ & $0.275^{* * *}$ & $0.307 * * *$ & $0.274 * * *$ & $0.305^{* * *}$ & $0.273 * * *$ \\
\hline & {$[0.024]$} & [0.017] & {$[0.024]$} & [0.017] & [0.024] & [0.017] \\
\hline \multirow[t]{2}{*}{ Bank Risk } & $0.045 * * *$ & $0.055^{* * *}$ & $0.043 * * *$ & $0.054 * * *$ & $0.043 * * *$ & $0.054 * * *$ \\
\hline & [0.009] & [0.007] & [0.009] & [0.007] & [0.009] & [0.007] \\
\hline Dummy & -0.140 & -0.140 & -0.126 & -0.138 & -0.145 & -0.144 \\
\hline Manufacturing sector & [0.127] & [0.097] & [0.127] & [0.097] & [0.127] & [0.097] \\
\hline \multirow{2}{*}{$\begin{array}{l}\text { Dummy Construction } \\
\text { sector }\end{array}$} & $-0.466 * * *$ & $-0.455^{* * *}$ & $-0.469 * * *$ & $-0.457 * * *$ & $-0.467 * * *$ & $-0.458 * * *$ \\
\hline & [0.136] & [0.103] & [0.136] & [0.103] & [0.136] & [0.103] \\
\hline Dummy Service sector & 0.041 & -0.121 & 0.044 & -0.121 & 0.037 & -0.124 \\
\hline & [0.129] & [0.098] & [0.129] & [0.098] & [0.129] & [0.098] \\
\hline Dummy firm province & YES & YES & YES & YES & YES & YES \\
\hline Bank fixed effects & YES & YES & YES & YES & YES & YES \\
\hline Dummy Year & YES & YES & YES & YES & YES & YES \\
\hline Constant & $71.272^{* * *}$ & $70.727 * * *$ & $71.661 * * *$ & $70.809 * * *$ & $71.265^{* * *}$ & $70.667 * * *$ \\
\hline & [2.040] & [1.654] & [2.042] & [1.655] & [2.039] & [1.654] \\
\hline N. obs & 712,005 & 782,253 & 712,005 & 782,253 & 712,005 & 782,253 \\
\hline Adjusted R-squared & 0.59 & 0.74 & 0.59 & 0.74 & 0.59 & 0.74 \\
\hline
\end{tabular}

Dependent variable: Percentage share of credit provided by bank $\mathrm{j}$ on the overall short-term loans of firm $\mathrm{i}$ at time $t$. Linear regressions with bank fixed effects; robust standard errors (in brackets) are clustered at firm level. Symbols ${ }^{*},{ }^{* *},{ }^{* *}$, respectively, indicate significance level at $10 \%, 5 \%$, and $1 \%$. 
Another interesting firm characteristic to analyse concerns differences in firms' financial riskiness, summarized by the Z-score index provided by CADS. To test whether consolidated banks, jointly financing the same firm, behave differently in terms of credit concentration depending on the ex-ante firm financial risk, we have interacted the firm Z-score with the dummy $D_{\text {MAMULTI }}$ (Table 6, columns V and VI). The findings show that lending banks reduce the concentration of their credit relationships exclusively towards the financially riskier firms: indeed, using both the share of credit built on credit actually used and that simply granted, the interaction variable between the dummy $D_{M A M U L T I}$ and the rating of the firm is negative and significant, underlining the 'flight-to-quality' strategy specifically followed by merged banks to reduce their commitment towards less healthy firms ${ }^{25}$ In addition, in this model, the estimated coefficient on the standalone $D_{M A M U L T I}$ is positive and significant, suggesting that the negative sign found on this dummy in the baseline specification (Table 4) depends exclusively on those banking relationships involving firms with financially distressed conditions.

\subsection{Specific Geographical Evidence: Lending Proximity and Firm Agglomerations}

A specific point that this paper addresses is the analysis of possible differential effects of bank M\&As on the concentration of credit relationships, in cases in which there is geographical proximity between bank and firm or there are firms belonging to spatial and economic agglomerations. From a theoretical point of view, as mentioned in the introduction, these differential factors could play opposite roles. On the one hand, they could make more effective the reduction of the total credit available to firms and provided by the new consolidated banks, since geographical proximity and firm agglomeration emphasize closer bank-firm credit relationships and the increasing degree of credit concentration. On the other hand, both firms and banks may have an incentive to preserve concentrated credit relationships, in order to take better advantage of gathering and using soft information.

The geographical proximity between banks and firms has a significant impact on relationship lending, as shown by the wide theoretical and empirical literature (Cerqueiro et al., 2009; Casolaro and Mistrulli, 2009). Larger banks, that have grown as a result of mergers and acquisitions, generally originate an increase in the functional distance between local branch managers and their general headquarters (Alessandrini et al., 2005); that is, moving decisional power in lending approval far away from local credit markets (regional or sub-regional) and increasing the information asymmetry

\footnotetext{
${ }^{25}$ A similar cleaning strategy was found by Alessandrini et al., (2008), especially in out-ofmarket acquisitions relative to the in-market deals.
} 
in credit assessment. ${ }^{26}$ To analyse the effect on credit relationships of the involvement of lending banks in the consolidation process, distinguishing the cases of geographically close bank branches or farther away branches relative to the borrowing firms, we added to the baseline specification a dummy calculated as the interaction between the dummies $D_{M A M U L T I}$ and $D_{P R O X}$.

The findings, based on credit used and granted, are reported in Table 7 (respectively, columns I and II). The parameters of the interacted variable (respectively, 1.23 and 1.05) are positive and significant, thus suggesting that closer relationships protect against a decrease in credit concentration following bank M\&As. Moreover, it is important to note that, measuring the share in terms of credit actually used by the firm, the increase of credit concentration estimated for closer consolidated banks completely offsets the decline of the share due to the need to diversify relationships after banking consolidation. It is also interesting to note that, by including the interacted variable in the regression, the parameter of $D_{M A M U L T I}$ becomes significantly higher than that measured by the baseline, which means that, for relationships not characterized by geographical proximity, the decline in the share of credit jointly provided by consolidated lenders is much more severe than that shown by basic estimates. These results clearly imply that the geographical proximity of lenders to borrowers is an important factor in protecting credit relationships in the case of exogenous shocks stemming from bank M\&As, which may hamper relationship lending to the detriment of soft information gathering. In other words, the operational proximity of bank branches in the same municipality where the firm is headquartered enhances the soft information and attempts to preserve closer or exclusive links between the parties.

Another interesting aspect at territorial level is the analysis of possible differential effects originating from firm agglomerations, such as the industrial districts, where it is more likely that there are close links between lenders and borrowers. In order to capture these effects, we included in the model a dummy accounting for firms belonging to industrial districts $\left(D_{D I S T}\right)$ and its interaction with the dummy for multiple bank M\&As $\left(D_{M A M U L T I}\right)$. In both configurations of credit used and granted (see Table 7 , columns III and IV), the interaction term is positive and significant (respectively, 0.73 and 0.60 ). This implies that consolidated banks, jointly providing finance to the same district firm, tend to reduce their exposure after consolidation to a lesser extent (or maintain almost unchanged). Even in this case, therefore, the willingness to protect existing credit relationships seems to prevail.

\footnotetext{
${ }^{26}$ Bank mergers exert an effect on the operational distance between the firm and the lending branch, whose cause and direction are however still ambiguous. With a growing network of branches throughout several credit markets, a phenomenon occurred jointly with bank mergers, it is likely that the operational distance has not been adversely affected by the reorganization of the banking system; this fact may have enhanced vis-à-vis relationships, partially offsetting bank organizational shocks on the supply-side.
} 
Table 7 - Different Effects by Bank-Firm Proximity and Firm Agglomerations

\begin{tabular}{|c|c|c|c|c|}
\hline & \multicolumn{2}{|c|}{ Geographical proximity } & \multicolumn{2}{|c|}{ Firms belonging to an Industrial District } \\
\hline & $\begin{array}{c}\text { Credit actually } \\
\text { used (I) }\end{array}$ & $\begin{array}{l}\text { Credit granted } \\
\text { (II) }\end{array}$ & $\begin{array}{l}\text { Credit actually used } \\
\text { (III) }\end{array}$ & $\begin{array}{l}\text { Credit granted } \\
\text { (IV) }\end{array}$ \\
\hline \multirow{2}{*}{ Share $_{j, \mathrm{i}, \mathrm{t}-3}$} & $0.730 * * *$ & $0.817^{* * *}$ & $0.730^{* * *}$ & $0.817^{* * *}$ \\
\hline & {$[0.002]$} & [0.002] & {$[0.002]$} & [0.002] \\
\hline \multirow[t]{2}{*}{$\mathrm{D}_{\mathrm{MA}}$} & -0.058 & 0.042 & -0.052 & 0.049 \\
\hline & {$[0.046]$} & [0.032] & {$[0.046]$} & [0.032] \\
\hline \multirow[t]{2}{*}{ Dмамulti } & $-1.237 * * *$ & $-1.472^{* * *}$ & $-0.612^{* * *}$ & $-0.926 * * *$ \\
\hline & [0.105] & {$[0.072]$} & {$[0.080]$} & {$[0.055]$} \\
\hline \multirow[t]{2}{*}{$D_{\text {PROX }}$} & $0.298^{* * *}$ & $0.225^{* * *}$ & $0.355^{* * *}$ & $0.281 * * *$ \\
\hline & [0.030] & {$[0.022]$} & [0.029] & [0.022] \\
\hline \multirow[t]{2}{*}{ Derox $^{*}$ D mamulti } & $1.226 * * *$ & $1.047^{* * *}$ & & \\
\hline & [0.132] & {$[0.088]$} & & \\
\hline \multirow{2}{*}{ Firm size } & $-0.434 * * *$ & $-0.353^{* * *}$ & $-0.431 * * *$ & $-0.350 * * *$ \\
\hline & [0.013] & [0.010] & [0.014] & [0.010] \\
\hline \multirow[t]{2}{*}{ Firm ROA } & $-0.012 * * *$ & 0.002 & $-0.012^{* * *}$ & 0.001 \\
\hline & [0.003] & [0.002] & [0.003] & [0.002] \\
\hline \multirow[t]{2}{*}{ Firm leverage } & $-0.005^{*}$ & $0.005 * * *$ & $-0.004 *$ & $0.005 * * *$ \\
\hline & [0.002] & [0.002] & [0.002] & {$[0.002]$} \\
\hline \multirow[t]{2}{*}{ Firm rating } & $0.069 * * *$ & $-0.198 * * *$ & $0.068^{* * *}$ & $-0.199 * * *$ \\
\hline & [0.010] & [0.007] & [0.010] & {$[0.007]$} \\
\hline \multirow[t]{2}{*}{ DDIST } & & & 0.055 & 0.012 \\
\hline & & & {$[0.046]$} & [0.032] \\
\hline \multirow[t]{2}{*}{$D_{\text {DIST }} * D_{\text {MAMULTI }}$} & & & $0.726^{* * *}$ & $0.602^{* * *}$ \\
\hline & & & [0.217] & [0.141] \\
\hline \multirow[t]{2}{*}{ Local credit market concentration } & 0.000 & $0.000^{* * *}$ & $0.000^{*}$ & $0.000 * * *$ \\
\hline & {$[0.000]$} & {$[0.000]$} & {$[0.000]$} & {$[0.000]$} \\
\hline \multirow[t]{2}{*}{ Bank size } & $-2.755 * * *$ & $-2.792 * * *$ & $-2.745 * * *$ & $-2.773 * * *$ \\
\hline & {$[0.086]$} & {$[0.070]$} & {$[0.086]$} & {$[0.070]$} \\
\hline \multirow[t]{2}{*}{ Bank ROA } & $0.301 * * *$ & $0.270 * * *$ & $0.303 * * *$ & $0.272 * * *$ \\
\hline & {$[0.024]$} & {$[0.017]$} & {$[0.024]$} & {$[0.017]$} \\
\hline \multirow[t]{2}{*}{ Bank risk } & $0.042^{* * *}$ & $0.053^{* * *}$ & $0.043^{* * *}$ & $0.053^{* * *}$ \\
\hline & {$[0.009]$} & [0.007] & [0.009] & [0.007] \\
\hline \multirow[t]{2}{*}{ Dummy Manufacturing sector } & -0.143 & -0.142 & -0.157 & -0.154 \\
\hline & [0.127] & {$[0.097]$} & [0.127] & {$[0.096]$} \\
\hline \multirow[t]{2}{*}{ Dummy Construction sector } & $-0.469 * * *$ & $-0.457 * * *$ & $-0.467 * * *$ & $-0.466 * * *$ \\
\hline & [0.136] & [0.103] & [0.135] & {$[0.102]$} \\
\hline \multirow[t]{2}{*}{ Dummy Service sector } & 0.038 & -0.122 & 0.039 & -0.126 \\
\hline & [0.129] & [0.098] & [0.128] & {$[0.097]$} \\
\hline Dummy firm province & YES & YES & YES & YES \\
\hline Bank fixed effects & YES & YES & YES & YES \\
\hline Dummy Year & YES & YES & YES & YES \\
\hline \multirow[t]{2}{*}{ Constant } & $71.088 * * *$ & $70.598 * * *$ & $70.768^{* * *}$ & $69.499 * * *$ \\
\hline & [2.038] & [1.653] & {$[2.042]$} & [1.662] \\
\hline N. obs & 712,005 & 782,253 & 705,483 & 775,330 \\
\hline Adjusted R-squared & 0.59 & 0.74 & 0.59 & 0.74 \\
\hline
\end{tabular}

Dependent variable: Percentage share of credit provided by bank $j$ on the overall short-term loans of firm $i$ at time t. Linear regressions with bank fixed effects; robust standard errors (in brackets) are clustered at firm level. Symbols ${ }^{*}{ }^{* *},{ }^{* * \star}$, respectively, indicate significance level at $10 \%, 5 \%$, and $1 \%$. 
Finally, the evidence presented in Table 7 suggests that when there is geographical proximity between firms and lenders, as well as in case of firm agglomerations, as in industrial districts, relationship banking is more resilient than elsewhere to external negative shocks that may arise from the banking consolidation process. Therefore, under these hypotheses, the banks' approach seems less oriented towards diversifying firm credit concentration and more devoted to following strategies to enhance soft information.

\section{Dropping or Switching Credit Relationships Af- ter M\&As: an Analysis of the Main Determi- nants}

The previous analysis has highlighted the slight decrease in the share of credit provided to firms by banks involved in mergers, when they were jointly financing the same company before the aggregation. However, it is important to point out that this effect, affecting the specific bank-firm relationships, does not necessarily imply a decline in the overall financial support to the firm. Thus, having available the whole mix of relationships over the period $t-3-t$, in which the bank consolidation occurs, we are able to investigate the motivations underlying the slight decrease in the share of credit measured previously. So, it is interesting to know to what extent the phenomenon depends on a real loss of relationships, due to the interruption of the relationship after M\&As, and to what degree it is instead due to a simple redistribution of the overall credit granted to the firm by different lenders, already in a relationship with the company or by new lenders.

In order to test the determinants of the decrease, we conducted a multinomial logit econometric exercise, by adopting an approach similar to that proposed by Degryse et al. (2011). In this case, the analysis was performed on a sub-sample containing, for each three-year period, only the bank-firm relationships already in existence at time $t-3$ (i.e., excluding the new relationship developed during the three years). We used this sub-sample for a multinomial logit analysis aimed at investigating to what extent M\&A re-organizations affect the probability that in the following three years the relationship will be lost ("drop") or there will be a reduction in the credit share of each relationship, and a likely switch towards other banks ("reduceswitch"), both in comparison to the basic outcome of a continuation or an expansion of the share of credit granted ("stay-increase"). To capture these effects we used both the dummy $D_{M A}$, indicating a bank's involvement in the concentration process, and the dummy $D_{M A M U L T I}$, capturing the simultaneous participation in the process of more than one lender. Having in mind the qualitative nature of the analysis, the main purpose was indeed to investigate the general trends that emerge after an aggregation and the mo- 
tivations that lead to changes in the relationship, distinguishing the cases involving several intermediaries in M\&As. Moreover, in order to take into account the importance of the single bank relationship on the overall credit to the firm, we also included as controls the credit share at the beginning of the three-year period and the variables that take into account the main characteristics at bank and firm level.

Results of the multinomial analysis, conducted for simplicity only on credit actually used, are reported in Table 8, which shows the basic estimate. In the following tables (9, 10 and 11), as already developed in the quantitative analysis previously outlined (Section 4), we present the estimates in which we control for the interactions between banks' involvement in M\&As and the main characteristics of the borrowing firms (such as risk and localization in a district municipality) or the proximity of the parties.

In the first model (Table 8 , column I), with respect to the basic case (preservation or increase of the relationship existing at the beginning of each reference period), the estimated coefficient is negative and significant for both the dummies $D_{M A}$ and $D_{M A M U L T I}$. This suggests that after an aggregation there is no evidence of an incentive to interrupt the credit relationship, even in the case of involvement of more than one lender, but the hypothesis of preservation or extension of the credit exposure is rather more likely. Really, in the case of reduce-switch (Table 8, column II), both for $D_{M A}$ and for $D_{M A M U L T I}$ we estimate a coefficient with a positive sign and high statistical significance: this indicates that the event of a bank M\&A actually increases the likelihood of a reduction in the importance of the credit relationship with intermediaries involved in aggregations in favour of other banks. In other words, the estimated limited drop in the share of credit resulting from the consolidation process of multiple lenders of the same firm is mainly due to the redistribution of credit towards other banks, already lenders to the firm or new entrants in the lender mix. The overall marginal effect (i.e., evaluated with respect both to the drop and to the stay-increase) of involvement in aggregations (dummy $D_{M A}$ and $D_{M A M U L T I}$ ) resulting from the hypothesis of a reduction of the share and a shift to other banks (reduceswitch) is positive and relatively high (0.049 and 0.047, respectively).

Moreover, always with respect to the basic outcome of maintaining or increasing exposure, the initial concentration of the credit relationship makes an interruption less likely, while it enhances the likelihood of reduction and switch towards other intermediaries, in order to contain the excessive risk of hold-up for the customer following the merger of its lenders. Then, other things being equal, for large banks and large companies interrupting the relationship is also more likely than maintaining or increasing it. Indeed, in this case it is likely that the organizational shock will be more severe on both sides, and so an interruption can occur more frequently than a simple reduction.

Another interesting finding concerns the geographical proximity of banks 
Table 8 - Multinomial Logit Estimation (mod. I - Baseline): Probability of "Dropping" or "ReducingSwitching" Vs. "Staying-Increasing"

\begin{tabular}{|c|c|c|c|c|}
\hline & \multicolumn{2}{|r|}{ Drop } & \multicolumn{2}{|c|}{ Reduce-Switch } \\
\hline & Coefficient & Marginal effects (1) & Coefficient & Marginal effects (1) \\
\hline Share $_{j, i, t-3}$ & $\begin{array}{c}-0.050 * * * \\
{[0.001]}\end{array}$ & -0.011 & $\begin{array}{c}0.025^{* * *} \\
{[0.001]}\end{array}$ & 0.011 \\
\hline $\mathrm{D}_{\mathrm{MA}}$ & $\begin{array}{c}-0.418^{* * *} \\
{[0.011]}\end{array}$ & -0.077 & $\begin{array}{c}0.050 * * * \\
{[0.009]}\end{array}$ & 0.049 \\
\hline Dмamulti & $\begin{array}{c}-0.169 * * * \\
{[0.021]}\end{array}$ & -0.039 & $\begin{array}{c}0.133 * * * \\
{[0.016]}\end{array}$ & 0.047 \\
\hline DPROX & $\begin{array}{c}-0.284^{* * *} \\
{[0.013]}\end{array}$ & -0.041 & $\begin{array}{c}-0.089 * * * \\
{[0.008]}\end{array}$ & 0.004 \\
\hline Firm size & $\begin{array}{c}0.031 * * * \\
{[0.009]}\end{array}$ & 0.001 & $\begin{array}{c}0.047 * * * \\
{[0.004]}\end{array}$ & 0.009 \\
\hline Firm ROA & $\begin{array}{c}-0.008 * * * \\
{[0.001]}\end{array}$ & -0.002 & $\begin{array}{c}0.008 * * * \\
{[0.001]}\end{array}$ & 0.003 \\
\hline Firm leverage & $\begin{array}{c}0.003^{* *} \\
{[0.001]}\end{array}$ & 0.000 & $\begin{array}{c}0.002 * * * \\
{[0.001]}\end{array}$ & 0.000 \\
\hline Firm rating & $\begin{array}{c}-0.166 * * * \\
{[0.006]}\end{array}$ & -0.036 & $\begin{array}{c}0.086 * * * \\
{[0.003]}\end{array}$ & 0.035 \\
\hline Local credit market concentration & $\begin{array}{c}-0.000^{* * *} \\
{[0.000]}\end{array}$ & -0.000 & $\begin{array}{c}-0.000^{* * *} \\
{[0.000]}\end{array}$ & -0.000 \\
\hline Bank size & $\begin{array}{c}0.127 * * * \\
{[0.004]}\end{array}$ & 0.026 & $\begin{array}{c}-0.042^{* * *} \\
{[0.003]}\end{array}$ & -0.021 \\
\hline Bank ROA & $\begin{array}{c}0.257 * * * \\
{[0.007]}\end{array}$ & 0.044 & $\begin{array}{c}0.001 \\
{[0.007]}\end{array}$ & -0.023 \\
\hline Bank risk & $\begin{array}{c}0.002 \\
{[0.002]}\end{array}$ & 0.000 & $\begin{array}{c}0.001 \\
{[0.002]}\end{array}$ & 0.000 \\
\hline Dummy Manufacturing sector & $\begin{array}{c}-0.064 \\
{[0.069]}\end{array}$ & -0.014 & $\begin{array}{c}0.038 \\
{[0.041]}\end{array}$ & 0.015 \\
\hline Dummy Construction sector & $\begin{array}{c}0.088 \\
{[0.075]}\end{array}$ & 0.001 & $\begin{array}{c}0.152^{* * *} \\
{[0.043]}\end{array}$ & 0.029 \\
\hline Dummy Service sector & $\begin{array}{l}-0.067 \\
{[0.070]}\end{array}$ & -0.018 & $\begin{array}{l}0.071^{*} \\
{[0.041]}\end{array}$ & 0.023 \\
\hline Dummy Year & YES & YES & YES & YES \\
\hline Constant & $\begin{array}{c}-2.107^{* * *} \\
{[0.142]}\end{array}$ & & $\begin{array}{c}-0.312^{* * *} \\
{[0.086]}\end{array}$ & \\
\hline $\begin{array}{l}\text { N. obs } \\
\text { Pseudo R-squared }\end{array}$ & & & $\begin{array}{l}909 \\
57\end{array}$ & \\
\hline
\end{tabular}

The dependent variable is a dummy equal to 1 in the case of dropped bank-firm relations in each 3-year period, 2 in the case of reduced share and switching towards other banks, 0 (the base-outcome) in the case of maintained relations and, generally, increased share. Multinomial logit estimation. Table reports estimated coefficients on the pooled bank-firm credit relations measured on the credit share actually used by firms at the beginning of each 3-year period, distinguishing three different alternatives over the following 3 years: interruption of credit relations (drop), or diversification (reduce-switch) of credit relationships towards other intermediaries, relative to the baseoutcome of stay-increase; robust standard errors are reported in brackets and are clustered at firm level. Symbols ${ }^{*},{ }^{* *},{ }^{* * *}$ respectively indicate a significance level of estimated parameters at $10 \%, 5 \%$ and $1 \%$. (1) Marginal effects account for the impact on a given alternative of each explicative variable relative to all other alternatives jointly considered, using average values for continuous variables and the change from 0 to 1 for dummy variables. 
to firms, which, as expected, makes both the drop and the reduce-switch hypotheses less likely, to the benefit of the stay-increase option. This highlights once again the incentive to preserve the value of soft information by closer credit relationships, in terms of geographical proximity. Moreover, as shown by the second model (Table 9), the role of proximity is relevant also to lending banks involved in M\&As: the proximity between the parties makes it more likely that credit relationships with respect to the drop and to the switch options will be maintained or strengthened, even after mergers involving geographically close banks.

Further, the financial fragility of the borrowing firm has an effect on the evolution of the relationship: if the risk increases (growing rating index), it is less likely that the relationship will be interrupted, with respect to the basic outcome (stay-increase), but it becomes more likely that it will be reduced and partly passed on to other intermediaries. This result is consistent with the literature and with what we showed about the evolution of the degree of concentration of credit relationships (see Section 4.1). The third model (Table 10), in which we introduced the interaction between dummy $D_{M A M U L T I}$ and the Z-score, also indicates that after an aggregation involving multiple lenders of the same company at the same time, bank behaviour is differentiated according to the financial fragility of the customer. Compared to the hypothesis of maintaining or increasing exposure, it is more likely that after M\&As the credit relationships will be dropped or diversified if they are kept with riskier firms, confirming the 'flight-to-quality' strategy followed by banks after the reorganization of their structure.

The relationship with district firms also matters, as we show in model IV (Table 11), in which we added the district firm dummy and its interaction with the dummy $D_{M A M U L T I}$ to the multinomial logit estimation. Indeed, the credit relationships with district firms are more likely to remain or grow, compared with the hypothesis of a drop, even if the lending banks are involved in the banking consolidation process.

\section{Conclusions}

Over the past two decades, the banking and the production systems have been affected by significant changes. On the one hand, the territorial structure of the credit supply has been influenced by a number of bank aggregations that have involved both large and local intermediaries. On the other hand, under the effects of a selection process produced by globalization and international competition, the production system has also changed, showing more sophisticated financial needs and so providing the incentive for firms to diversify their credit relationships away from local banks towards other larger intermediaries. Given this, we examined whether and to what extent the growth in size and in organizational complexity of banks involved in mergers and acquisitions has affected their relationship mix, tak- 
Table 9 - Multinomial Logit Estimation (mod. II - Bank-Firm Proximity): Probability of "Dropping" or "Reducing-Switching" Vs. "Staying-Increasing"

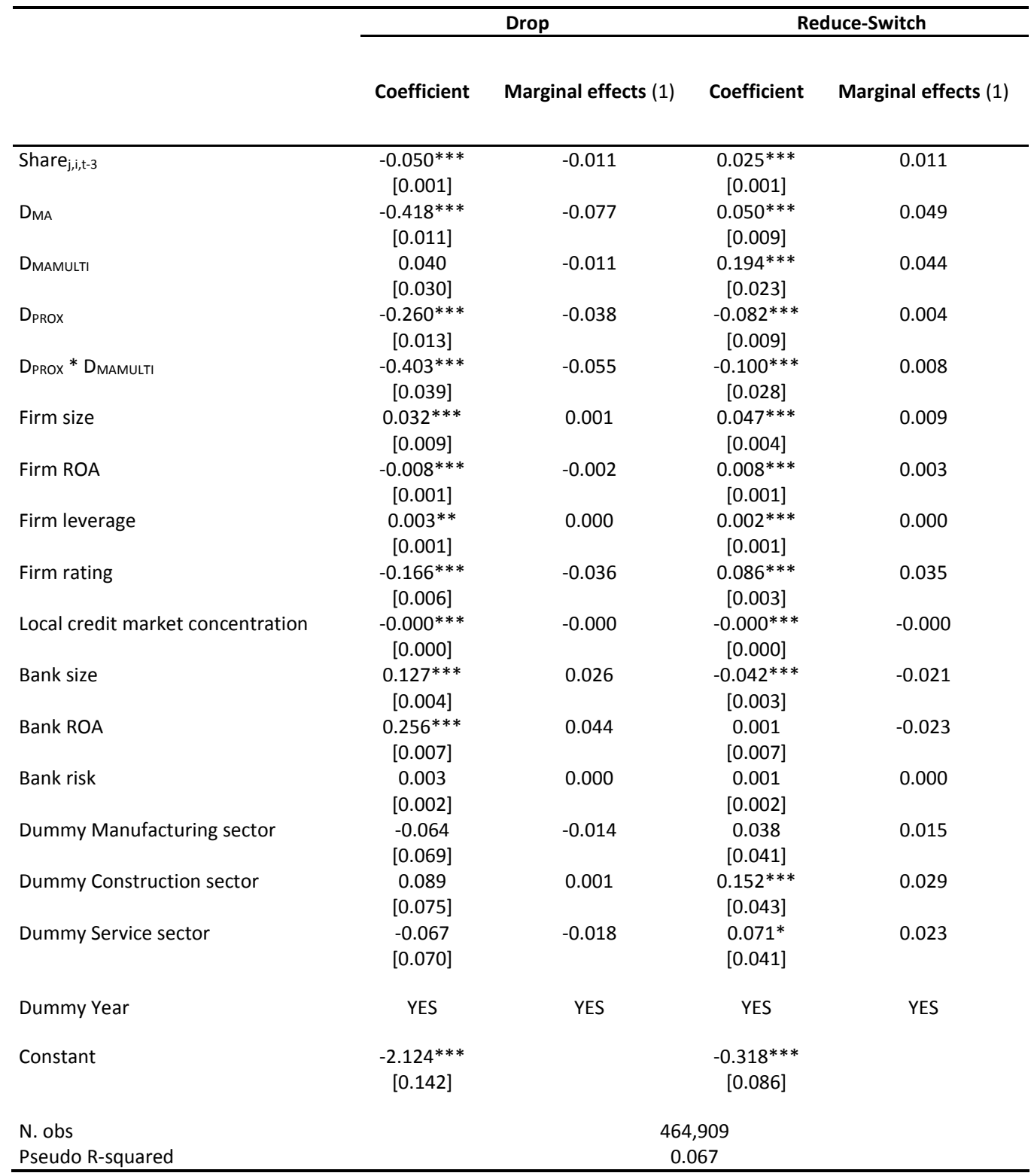

The dependent variable is a dummy equal to 1 in the case of dropped bank-firm relations in each 3-year period, 2 in the case of reduced share and switching towards other banks, 0 (the base-outcome) in the case of maintained relations and, generally, increased share. Multinomial logit estimation. Table reports estimated coefficients on the pooled bank-firm credit relations measured on the credit share actually used by firms at the beginning of each 3-year period, distinguishing three different alternatives over the following 3 years: interruption of credit relations (drop), or diversification (reduce-switch) of credit relationships towards other intermediaries, relative to the baseoutcome of stay-increase; robust standard errors are reported in brackets and are clustered at firm level. Symbols ${ }^{*},{ }^{* *},{ }^{* * *}$ respectively indicate a significance level of estimated parameters at $10 \%, 5 \%$ and $1 \%$. (1) Marginal effects account for the impact on a given alternative of each explicative variable relative to all other alternatives jointly considered, using average values for continuous variables and the change from 0 to 1 for dummy variables. 
Table 10 - Multinomial Logit Estimation (mod. III - Firm Rating): Probability of "Dropping" or "ReducingSwitching" Vs. "Staying-Increasing"

\begin{tabular}{|c|c|c|c|c|}
\hline & \multicolumn{2}{|r|}{ Drop } & \multicolumn{2}{|c|}{ Reduce-Switch } \\
\hline & Coefficient & Marginal effects (1) & Coefficient & Marginal effects (1) \\
\hline Share $_{j, \mathrm{i}, \mathrm{t}-3}$ & $\begin{array}{c}-0.050^{* * *} \\
{[0.001]}\end{array}$ & -0.011 & $\begin{array}{c}0.025 * * * \\
{[0.001]}\end{array}$ & 0.011 \\
\hline $\mathrm{D}_{\mathrm{MA}}$ & $\begin{array}{c}-0.418^{* * *} \\
{[0.011]}\end{array}$ & -0.077 & $\begin{array}{c}0.050 * * * \\
{[0.009]}\end{array}$ & 0.049 \\
\hline Dмamulti & $\begin{array}{c}-0.284 * * * \\
{[0.070]}\end{array}$ & -0.047 & $\begin{array}{c}0.025 \\
{[0.052]}\end{array}$ & 0.030 \\
\hline Derox & $\begin{array}{c}-0.284^{* * *} \\
{[0.013]}\end{array}$ & -0.041 & $\begin{array}{c}-0.089 * * * \\
{[0.008]}\end{array}$ & 0.004 \\
\hline Firm size & $\begin{array}{c}0.031^{* * *} \\
{[0.009]}\end{array}$ & 0.001 & $\begin{array}{c}0.047^{* * *} \\
{[0.004]}\end{array}$ & 0.009 \\
\hline Firm ROA & $\begin{array}{c}-0.008 * * * \\
{[0.001]}\end{array}$ & -0.002 & $\begin{array}{c}0.008 * * * \\
{[0.001]}\end{array}$ & 0.003 \\
\hline Firm leverage & $\begin{array}{c}0.003 * * \\
{[0.001]}\end{array}$ & 0.000 & $\begin{array}{c}0.002 * * * \\
{[0.001]}\end{array}$ & 0.000 \\
\hline Firm rating & $\begin{array}{c}-0.168^{* * *} \\
{[0.006]}\end{array}$ & -0.036 & $\begin{array}{c}0.084^{* * *} \\
{[0.003]}\end{array}$ & 0.035 \\
\hline Firm rating $*$ D $_{\text {MAMULTI }}$ & $\begin{array}{l}0.022^{*} \\
{[0.013]}\end{array}$ & 0.002 & $\begin{array}{c}0.020^{* *} \\
{[0.009]}\end{array}$ & 0.003 \\
\hline Local credit market concentration & $\begin{array}{c}-0.000 * * * \\
{[0.000]}\end{array}$ & -0.000 & $\begin{array}{c}-0.000 * * * \\
{[0.000]}\end{array}$ & -0.000 \\
\hline Bank size & $\begin{array}{c}0.127^{* * *} \\
{[0.004]}\end{array}$ & 0.026 & $\begin{array}{c}-0.042^{* * *} \\
{[0.003]}\end{array}$ & -0.021 \\
\hline Bank ROA & $\begin{array}{c}0.257 * * * \\
{[0.007]}\end{array}$ & 0.044 & $\begin{array}{c}0.001 \\
{[0.007]}\end{array}$ & -0.023 \\
\hline Bank risk & $\begin{array}{c}0.003 \\
{[0.002]}\end{array}$ & 0.000 & $\begin{array}{c}0.001 \\
{[0.002]}\end{array}$ & 0.000 \\
\hline Dummy Manufacturing sector & $\begin{array}{l}-0.064 \\
{[0.069]}\end{array}$ & -0.014 & $\begin{array}{c}0.038 \\
{[0.041]}\end{array}$ & 0.015 \\
\hline Dummy Construction sector & $\begin{array}{c}0.088 \\
{[0.075]}\end{array}$ & 0.001 & $\begin{array}{c}0.152^{* * *} \\
{[0.043]}\end{array}$ & 0.029 \\
\hline Dummy Service sector & $\begin{array}{l}-0.067 \\
{[0.070]}\end{array}$ & -0.018 & $\begin{array}{l}0.071^{*} \\
{[0.041]}\end{array}$ & 0.023 \\
\hline Dummy Year & YES & YES & YES & YES \\
\hline Constant & $\begin{array}{c}-2.100 * * * \\
{[0.142]}\end{array}$ & & $\begin{array}{c}-0.303^{* * *} \\
{[0.086]}\end{array}$ & \\
\hline $\begin{array}{l}\text { N. obs } \\
\text { Pseudo R-squared }\end{array}$ & & $\begin{array}{r}46 \\
0 .\end{array}$ & $\begin{array}{l}909 \\
67\end{array}$ & \\
\hline
\end{tabular}

The dependent variable is a dummy equal to 1 in the case of dropped bank-firm relations in each 3-year period, 2 in the case of reduced share and switching towards other banks, 0 (the base-outcome) in the case of maintained relations and, generally, increased share. Multinomial logit estimation. Table reports estimated coefficients on the pooled bank-firm credit relations measured on the credit share actually used by firms at the beginning of each 3-year period, distinguishing three different alternatives over the following 3 years: interruption of credit relations (drop), or diversification (reduce-switch) of credit relationships towards other intermediaries, relative to the baseoutcome of stay-increase; robust standard errors are reported in brackets and are clustered at firm level. Symbols ${ }^{*},{ }^{* *}, * * *$ respectively indicate a significance level of estimated parameters at $10 \%, 5 \%$ and $1 \%$. (1) Marginal effects account for the impact on a given alternative of each explicative variable relative to all other alternatives jointly considered, using average values for continuous variables and the change from 0 to 1 for dummy variables. 
Table 11 - Multinomial Logit Estimation (mod. IV - Firm Belonging to Industrial Districts): Probability of "Dropping" or "Reducing-Switching" Vs. "Staying-Increasing"

\begin{tabular}{|c|c|c|c|c|}
\hline & \multicolumn{2}{|r|}{ Drop } & \multicolumn{2}{|c|}{ Reduce-Switch } \\
\hline & Coefficient & Marginal effects (1) & Coefficient & Marginal effects (1) \\
\hline Share $_{j, i, t-3}$ & $\begin{array}{c}-0.051^{* * *} \\
{[0.001]}\end{array}$ & -0.011 & $\begin{array}{c}0.025^{* * *} \\
{[0.001]}\end{array}$ & 0.011 \\
\hline $\mathrm{D}_{\mathrm{MA}}$ & $\begin{array}{c}-0.428^{* * *} \\
{[0.011]}\end{array}$ & -0.078 & $\begin{array}{c}0.047^{* * *} \\
{[0.009]}\end{array}$ & 0.050 \\
\hline D MAMULTI & $\begin{array}{c}-0.162^{* * *} \\
{[0.022]}\end{array}$ & -0.038 & $\begin{array}{c}0.135^{* * *} \\
{[0.017]}\end{array}$ & 0.047 \\
\hline DPROX & $\begin{array}{c}-0.281^{* * *} \\
{[0.013]}\end{array}$ & -0.041 & $\begin{array}{c}-0.088^{* * *} \\
{[0.008]}\end{array}$ & 0.004 \\
\hline Firm size & $\begin{array}{c}0.028^{* * *} \\
{[0.009]}\end{array}$ & 0.001 & $\begin{array}{c}0.047^{* * *} \\
{[0.004]}\end{array}$ & 0.009 \\
\hline Firm ROA & $\begin{array}{c}-0.008^{* * *} \\
{[0.001]}\end{array}$ & -0.002 & $\begin{array}{c}0.008^{* * *} \\
{[0.001]}\end{array}$ & 0.003 \\
\hline Firm leverage & $\begin{array}{l}0.003^{*} \\
{[0.001]}\end{array}$ & 0.000 & $\begin{array}{c}0.002 * * * \\
{[0.001]}\end{array}$ & 0.000 \\
\hline Firm rating & $\begin{array}{c}-0.167^{* * *} \\
{[0.006]}\end{array}$ & -0.036 & $\begin{array}{c}0.086^{* * *} \\
{[0.003]}\end{array}$ & 0.036 \\
\hline D DIST & $\begin{array}{c}-0.111^{* * *} \\
{[0.025]}\end{array}$ & -0.016 & $\begin{array}{l}-0.025^{*} \\
{[0.013]}\end{array}$ & 0.004 \\
\hline Dist $*$ DMAMULTI & $\begin{array}{c}-0.129 * * \\
{[0.065]}\end{array}$ & -0.020 & $\begin{array}{c}-0.021 \\
{[0.043]}\end{array}$ & 0.006 \\
\hline Local credit market concentration & $\begin{array}{c}-0.000 * * * \\
{[0.000]}\end{array}$ & -0.000 & $\begin{array}{c}-0.000 * * * \\
{[0.000]}\end{array}$ & -0.000 \\
\hline Bank size & $\begin{array}{c}0.128 * * * \\
{[0.004]}\end{array}$ & 0.026 & $\begin{array}{c}-0.041^{* * *} \\
{[0.003]}\end{array}$ & -0.021 \\
\hline Bank ROA & $\begin{array}{c}0.255^{* * *} \\
{[0.007]}\end{array}$ & 0.044 & $\begin{array}{c}0.001 \\
{[0.007]}\end{array}$ & -0.022 \\
\hline Bank risk & $\begin{array}{c}0.003 \\
{[0.002]}\end{array}$ & 0.000 & $\begin{array}{c}0.001 \\
{[0.002]}\end{array}$ & 0.000 \\
\hline Dummy Manufacturing sector & $\begin{array}{c}-0.043 \\
{[0.069]}\end{array}$ & -0.011 & $\begin{array}{c}0.040 \\
{[0.041]}\end{array}$ & 0.013 \\
\hline Dummy Construction sector & $\begin{array}{c}0.087 \\
{[0.075]}\end{array}$ & 0.001 & $\begin{array}{c}0.148^{* * *} \\
{[0.043]}\end{array}$ & 0.028 \\
\hline Dummy Service sector & $\begin{array}{c}-0.068 \\
{[0.070]}\end{array}$ & -0.018 & $\begin{array}{l}0.068^{*} \\
{[0.041]}\end{array}$ & 0.022 \\
\hline Dummy Year & YES & YES & YES & YES \\
\hline Constant & $\begin{array}{c}-2.072 * * * \\
{[0.143]}\end{array}$ & & $\begin{array}{c}-0.330^{* * *} \\
{[0.087]}\end{array}$ & \\
\hline $\begin{array}{l}\text { N. obs } \\
\text { Pseudo R-squared }\end{array}$ & & & & \\
\hline
\end{tabular}

The dependent variable is a dummy equal to 1 in the case of dropped bank-firm relations in each 3-year period, 2 in the case of reduced share and switching towards other banks, 0 (the base-outcome) in the case of maintained relations and, generally, increased share. Multinomial logit estimation. Table reports estimated coefficients on the pooled bank-firm credit relations measured on the credit share actually used by firms at the beginning of each 3-year period, distinguishing three different alternatives over the following 3 years: interruption of credit relations (drop), or diversification (reduce-switch) of credit relationships towards other intermediaries, relative to the baseoutcome of stay-increase; robust standard errors are reported in brackets and are clustered at firm level. Symbols ${ }^{*},{ }^{* *},{ }^{* * *}$ respectively indicate a significance level of estimated parameters at $10 \%, 5 \%$ and $1 \%$. (1) Marginal effects account for the impact on a given alternative of each explicative variable relative to all other alternatives jointly considered, using average values for continuous variables and the change from 0 to 1 for dummy variables. 
ing into account the different nature and risks of borrowing firms and the characteristics of their banking relationships, in terms of geographical proximity and informational spillovers, arising from firms belonging to specific economic sectors or spatial agglomerations.

The share of finance lent by each bank on total firm loans is, in our opinion, the best proxy of the strength of the link between the parties. Although the degree of concentration of the credit relationship is only one of the features of relationship lending, it represents the most tangible and accurately measurable characteristic. Therefore, given the availability of matched bank-firm data, this paper has evaluated the effect of bank M\&As on the degree of concentration of individual credit relationships, comparing pro-forma homogeneous banks over each three-year reference period in the time span 1999-2009. When a firm is financed by several banks jointly involved in consolidations, the automatic result is an increase in the concentration of the new single credit line; so, assessing whether this effect - on a given bank-firm relationship - is preserved or not in the years following the aggregation, allows us to investigate the extent to which the concentration of relationships is jointly evaluated by banks and firms as an "asset" to be enhanced or as a "cost" to be faced.

The main results of this paper indicate that, after an aggregation of several banks that before the deal were jointly financing the same firm, there is a slight reduction over three years of the share of credit provided to the firm by the new consolidated bank relative to the others. This does not necessarily cause a decrease in the overall credit granted to the firm: in an econometric exercise on the determinants of this change, we find that consolidations generate a higher probability of redistribution of overall firm credit among several lenders, rather than an interruption of relationships. However, geographically close relationships improve information gathering: knowledge between the parties reduces information costs for banks, also fostering access to credit for enterprises, especially under uncertainty scenarios, as in the recent crisis. In line with this effect, some insights also stem from different territorial and relationship features. The evidence shows that the reduction in the credit share, observed when more lenders of the same borrower merge, is mitigated when banks and firms are geographically close, or when the borrowing firm operates in areas with fewer negative context externalities (Centre-North) or in an industrial district, or when the firm has a less risky financial and economic situation. These findings support previous empirical evidence that showed a less effective rationing of firms with these characteristics, due to closer and long-lasting relationships with local banks and to the higher investment in soft information made by their relationship-based lenders. 


\section{References}

Accetturo, A., Giunta, A., Rossi, S., 2011. Le imprese italiane tra crisi e nuova globalizzazione. Questioni di Economia e Finanza. Bank of Italy. No. 86, January.

Alessandrini, P., Calacagnini, G., Zazzaro, A., 2008. Asset Restructuring Strategies in Bank Acquisitions: Does Distance Between Dealing Partners Matter? Journal of Banking \& Finance 32, 699-713. doi:10.1016/j.jbankfin.2007.05.008

Alessandrini, P., Croci, M., Zazzaro, A., 2005. The Geography of Banking Power: the Role of Functional Distance. BNL Quarterly Review LVIII, 129167.

Alessandrini, P., Fratianni, M., Zazzaro, A. (Eds.), 2009. The Changing Geography of Banking and Finance. Heidelberg: Springer-Verlag.

Alessandrini, P., Presbitero, A.F., Zazzaro, A., 2008. Banche e imprese nei distretti industriali. In: Zazzaro, A. (Ed.), I vincoli finanziari alla crescita delle imprese. Carocci, Rome.

Alessandrini, P., Zazzaro A. 2009. Bank's Localism and Industrial Districts. In: Becattini, G., Bellandi, M., De Propis, L. (Eds.), A Handbook of Industrial Districts. Edward Elgar Publishing Limited.

Baffigi, A., Pagnini, M., Quintiliani, F., 2000. Industrial Districts and Local Banks: Do the Twins Ever Meet? Temi di Discussione. Bank of Italy. No. 347, March.

Bank of Italy 2007. Annual Report on 2006. Rome, May.

Becattini, G., Bellandi, M., De Propis, L. (Eds.), 2009. A Handbook of Industrial Districts. Edward Elgar Publishing, Inc.. Cheltenham. doi:10.4337/9781781007808

Beretta, E., Del Prete, S., 2007. Aggregazioni bancarie e specializzazione nel credito alle PMI: peculiarità per area geografica. Temi di Discussione. Bank of Italy. No.644, November.

Beretta, E., Del Prete, S., 2012. Bank Acquisitions and Decentralization Choices. Economic Notes 41, 27-57. doi:10.1111/j.1468-0300.2012.00237.x

Berger, A.N., Saunders, A., Scalise, J.M., Udell, G.F., 1998. The Effects of Bank Mergers and Acquisitions on Small Business Lending. Journal of Financial Economics 50. 
Berger, A.N., Udell, G.F., 2002. Small Business Credit Availability and Relationship Lending: the Importance of Bank Organisational Structure. The Economic Journal 112, f32-f53. doi:10.1111/1468-0297.00682

Berger, A.N., Udell, G.F., 2006. A More Complete Conceptual Framework for SME Finance. Journal of Banking \& Finance 30, 2945-2966. doi:10.1016/j.jbankfin.2006.05.008

Bonaccorsi di Patti, E., 2009. Legalità e credito: l'impatto della criminalità sui prestiti alle imprese. In: Cannari, L. (Ed.), Mezzogiorno e politiche regionali. Bank of Italy. Seminari e Convegni, No. 2, November, pp. 165-190.

Bonaccorsi di Patti, E., Eramo, G., Gobbi, G., 2005. Piccole e grandi banche nel mercato del credito in Italia. Banca Impresa Società 1, 3-34.

Bonaccorsi di Patti, E., Gobbi, G., 2001. The Effects of Bank Consolidation and Market Entry on Small Business Lending. Temi di Discussione. Bank of Italy. No. 404.

Bonaccorsi di Patti, E., Gobbi, G., 2007. Winners or Losers? The Effects of Banking Consolidation on Corporate Borrowers. Journal of Finance 62, 669-695. doi:10.1111/j.1540-6261.2007.01220.x

Boot, A.W.A., 2000. Relationship Banking: What Do We Know? Journal of Financial Intermediation 9, 3-25. doi:10.1006/jfin.2000.0282

Bracchi, G., Masciandaro, D. (Eds.), 2006. Banche e Geografia, XI Rapporto sul sistema finanziario. Fondazione Rosselli, Rome.

Brandolini, A., Bugamelli, M., (Eds.), 2009. Rapporto sulle tendenze del sistema produttivo italiano. Questioni di Economia e Finanza. Bank of Italy. No. 45, April.

Cannari, L., (Ed.), 2009. Mezzogiorno e politiche regionali. Bank of Italy. Seminari e Convegni, No. 2, November.

Cannari, L., Pagnini, M., Rossi, P., (Eds.), 2010. Banks, Local Credit Markets and Credit Supply. Bank of Italy. Seminari e Convegni, No. 5, August.

Carmignani, A., Omiccioli, M., 2007. Costs and Benefits of Creditor Concentration: An Empirical Approach. Temi di Discussione. Bank of Italy. No. 645, November.

Casolaro, L., Mistrulli, P.E., 2009. Distance, Lending Technologies and Interest Rates, mimeo. Bank of Italy.

Cerqueiro, G., Degryse, H., Ongena, S., 2009. Distance, Bank Organizational Structure, and Credit. In: Alessandrini, P., Fratianni, M., Zazzaro, A., (Eds.), The Changing Geography of Banking and Finance. Heidelberg: Springer-Verlag, pp. 54-74. doi:10.1007/978-0-387-98078-2_4 
Degryse, H., Masschelein, N., Mitchell, J., 2011. Staying, Dropping, or Switching: The Impacts of Bank Mergers on Small Firms. Review of Financial Studies 24, 1102-1140. doi:10.1093/rfs/hhp126

Degryse, H., Ongena, S., 2001. Bank Relationships and Firm Performance. Financial Management 30, 9-34. doi:10.2307/3666389

Degryse, H., Ongena, S., 2007. The Impact of Competition on Bank Orientation. Journal of Financial Intermediation 16, 399-424. doi:10.1016/j.jfi.2007.03.002

Degryse, H., Van Cayseele, P., 2000. Relationship Lending within a Bank Based System: Evidence form European Small Business Data. Journal of Financial Intermediation 9, 90-109. doi:10.1006/jfin.1999.0278

Detragiache, E., Garella, P., Guiso, L., 2000. Multiple versus Single Banking Relationships: Theory and Evidence. Journal of Finance LV.

Ferri, G., Rotondi, Z., 2006. Does Finance Matter in the Re-Specialization of Italy's Industrial Districts? In: Bracchi, G., Masciandaro, D., (Eds.), Banche e Geografia, XI Rapporto sul sistema finanziario. Fondazione Rosselli, Rome, pp. 397-433.

Finaldi Russo, P., Rossi, P., 2001. Credit Constraints in Italian Industrial Districts. Applied Economics 33, 1469-1477. doi:10.1080/00036840010010467

Focarelli, D., Panetta, F., Salleo, C., 2002. Why Do Banks Merge? Journal of Money, Credit and Banking 34, 1047-1066. doi:10.1353/mcb.2002.0054

Gobbi, G., Sette, E., 2013. Do Firms Benefit from Concentrating their Borrowing? Evidence from the Great Recession. Review of Finance. 17, 1-34.

Herrera, A.M., Minetti, R., 2007. Informed Finance and Technological Change: Evidence from Credit Relationships. Journal of Financial Economics 83, 223-269. doi:10.1016/j.jfineco.2005.12.001

Hauswald, R., Marquez, R., 2006. Competition and Strategic Information Acquisition in Credit Markets. Review of Financial Studies 19, 967-1000. doi:10.1093/rfs/hhj021

Intesa-SanPaolo 2008. Monitor dei Distretti, Servizio Studi e Ricerche, December.

Intesa-SanPaolo 2009. Economia e finanza dei distretti industriali, Annual Report, No. 2, December.

Istat 2001. Ottavo Censimento generale dell'industria e dei servizi. Distretti industriali e sistemi locali del lavoro 2001, Rome. 
Iuzzolino, G., 2005. Le agglomerazioni territoriali di imprese nell'industria italiana. In: Signorini, L.F., Omiccioli, M., (Eds.), Economie locali e competizione globale: il localismo industriale italiano di fronte a nuove sfide. Il Mulino, Bologna, pp. 41-64.

Magri, S., 2009. The Financing of Small Innovative Firms: The Italian Case. Economics of Innovation and New Technology 18, 181-204. doi:10.1080/10438590701738016

Micucci, G., Rossi, P., 2010. Debt Restructuring and the Role of Lending Technologies. In: Cannari, L., Pagnini, M., Rossi, P., (Eds.), Banks, Local Credit Markets and Credit Supply. Bank of Italy. Seminari e Convegni, No. 5, August, pp. 143-173.

Micucci, G., Rossi, P., 2011. Financing R\&D Investments: Relationship Lending or Financial Markets? Bank of Italy. Mimeo.

OECD 2003. ICT and Economic Growth. Evidence from OECD Countries, Industries and Firms. OECD Publishing, Paris.

Ongena, S., Smith, D.C., 2001. The Duration of Bank Relationships. Journal of Financial Economics 61, 449-475. doi:10.1016/S0304-405X(01)00069-1

Pagano, M., 2000. Banche e distretti industriali: una relazione speciale? In: Signorini, L.F., (Ed.), Lo sviluppo locale. Un'indagine della Banca d'Italia sui distretti industriali. Meridiana Libri, Rome, pp. 155-165.

Pagnini, M., 2000. I vincoli finanziari per le imprese distrettuali: un'analisi sui dati bancari. In: Signorini, L.F., (Ed.), Lo sviluppo locale. Un'indagine della Banca d'Italia sui distretti industriali. Meridiana Libri, Rome, pp. 257269.

Petersen, M.A., Rajan, R.G., 1994. The Benefit of Lending Relationships: Evidence from Small Business Data. Journal of Finance 49, 3-37. doi:10.1111/j.1540-6261.1994.tb04418.x

Petersen, M.A., Rajan, R.G., 1995. The Effect of Credit Market Competition on Lending Relationships. The Quarterly Journal of Economics 110, 407443. doi:10.2307/2118445

Presbitero, A.F., Zazzaro, A., 2011. Competition and Relationship Lending: Friends or Foes? Journal of Financial Intermediation 20, 387-413. doi:10.1016/j.jfi.2010.09.001

Rabellotti, R., Carabelli, A., Hirsch, G., 2009. Italian Industrial Districts on the Move: Where Are They Going? European Planning Studies 17, 19-41. doi:10.1080/09654310802513914 
Sapienza, P., 2002. The Effects of Banking Mergers on Loan Contracts. Journal of Finance LVII, 329-367. doi:10.1111/1540-6261.00424

Signorini, L.F., Omiccioli, M., (Eds.), 2005. Economie locali e competizione globale: il localismo industriale italiano di fronte a nuove sfide. Il Mulino, Bologna.

Signorini, L.F., (Ed.), 2000. Lo sviluppo locale. Un'indagine della Banca d'Italia sui distretti industriali. Meridiana Libri, Rome.

Zazzaro, A., (Ed.), 2008. I vincoli finanziari alla crescita delle imprese. Carocci, Rome. 


\section{Methodological Appendix: Building the Dataset}

The building system of the dataset "by steps" runs as follows. Starting with a specific couple of years $t-3$ and $t$ (e.g. 1999 and 2002), for each firm $i$ belonging to our sample we consider all banking relationships; for each bank $j$ we calculate the share with which it contributes to the overall funding of the firm $i$, both in the period $t-3$ (Share ${ }_{j, i, t-3}$ ) and in the period $t$ $\left(\right.$ Share $\left._{j, i, t}\right)$. This process is repeated for all the firms belonging to the sample, regardless of whether their banks have been involved in the consolidation process or not in each three-year period. The result is a set (block) of observations relating to the years 1999-2002 as follows (where $A, B, C, \ldots$ represent banks $j$, and $x, y, z, \ldots$ firms $i$ ):

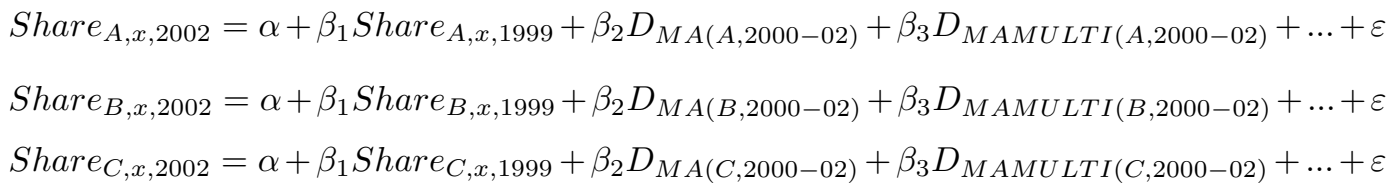

Share $_{A, y, 2002}=\alpha+\beta_{1}$ Share $_{A, y, 1999}+\beta_{2} D_{M A(A, 2000-02)}+\beta_{3} D_{M A M U L T I(A, 2000-02)}+\ldots+\varepsilon$

Share $_{B, y, 2002}=\alpha+\beta_{1}$ Share $_{B, y, 1999}+\beta_{2} D_{M A(B, 2000-02)}+\beta_{3} D_{M A M U L T I(B, 2000-02)}+\ldots+\varepsilon$ Share $_{C, y, 2002}=\alpha+\beta_{1}$ Share $_{C, y, 1999}+\beta_{2} D_{M A(C, 2000-02)}+\beta_{3} D_{M A M U L T I(C, 2000-02)}+\ldots+\varepsilon$

Share $_{A, z, 2002}=\alpha+\beta_{1}$ Share $_{A, z, 1999}+\beta_{2} D_{M A(A, 2000-02)}+\beta_{3} D_{M A M U L T I(A, 2000-02)}+\ldots+\varepsilon$

Share $_{B, z, 2002}=\alpha+\beta_{1}$ Share $_{B, z, 1999}+\beta_{2} D_{M A(B, 2000-02)}+\beta_{3} D_{M A M U L T I}(B, 2000-02)+\ldots+\varepsilon$ Share $_{C, z, 2002}=\alpha+\beta_{1}$ Share $_{C, z, 1999}+\beta_{2} D_{M A(C, 2000-02)}+\beta_{3} D_{M A M U L T I(C, 2000-02)}+\ldots+\varepsilon$

The dummies $D_{M A}$ shown in these equations (from which, for brevity, we omit all the controls) are equal to 1 for the banks that participated in at least one consolidation in the three-year period (i.e. between the beginning of 2000 and the end of 2002). Instead the dummies $D_{M A M U L T I}$ are equal to 1 only if the consolidation involving bank $j$ involved at least one other bank that financed the firm at the beginning of the period.

Once the building of the first block relative to the couple of years 19992002 is completed, we take into account the next three-year period (20002003), and we build another block with the identical methodology. It is important to note that, in this second step, we observe once again most of the bank-firm relationships already considered in the previous one, but on a different time span; moreover, bank $j$ is partly different, representing by means of the pro-forma balance sheets the situation of the consolidated banks at the end of 2003 and not in 2002. So, M\&A dummies will be equal to 1 in this 


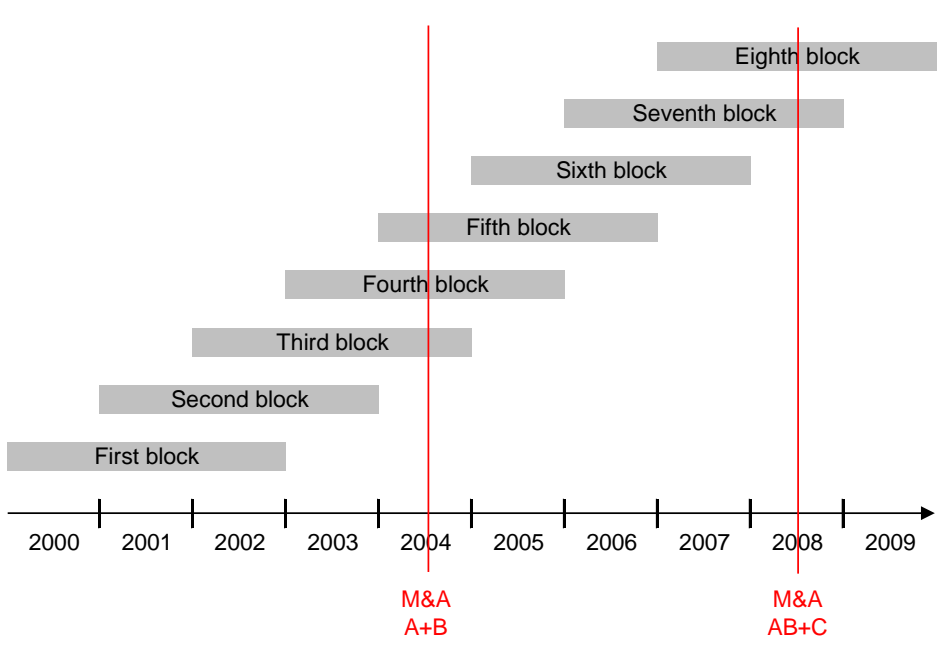

$\begin{array}{ccc}\text { Bank } & \text { Firm } & \text { Dum MA } \\ \text { ABC } & x & 1 \\ \text { ABC } & x & 1 \\ A B & x & 0 \\ A B & x & 1 \\ A B & x & 1 \\ A B & x & 1 \\ A & x & 0 \\ A & x & 0\end{array}$

case for banks involved in the concentration process between the beginning of 2001 and the end of 2003.

Once all the blocks of equations related to the time periods of interest (from 1999-2002 to 2006-2009) have been built, we pool the three-year periods and we estimate equations with the method indicated in the text (linear regression models with bank fixed effects and correction of standard errors for clusters of firms).

To better clarify the advantages of this approach, the example in the figure may be useful, reporting the case of a firm $x$ included in the sample throughout the period. The example will consider only the dummy $D_{M A}$, but it is easy to see that, with appropriate adjustments, the same considerations apply to the dummy $D_{M A M U L T I}$.

At the beginning of the period firm $x$ had a relationship with bank $A$; between 2000 and 2009, bank $A$ first incorporated bank $B$ (in 2004), then bank $C$ (in 2008). The example shows that this banking relationship is considered eight times, in many blocks of equations as described above, each examining the variation in a specific period of the share that the bank holds on the overall funding of the firm $x$. The "bank" to which we refer is $A$ for the three-year periods terminating in the years 2002 and 2003; it becomes $A B$ from the first block which includes the year of the first incorporation (i.e. for the intervals ending with the years 2004, 2005, 2006 and 2007); finally, it becomes $A B C$ from the first block that includes the year of the second incorporation (those ending in the years 2008 and 2009). The dummies are equal to 1 in every three-year period in which banks are involved in M\&As.

The "block" approach is quite complex, but the alternative of using a traditional panel was unsatisfactory, causing a loss of information. In fact, in this case, for the building of pro-forma balance sheet data it would have 
been necessary to merge all the banks, directly and indirectly incorporated or acquired throughout the examined period. This would have produced a snapshot of the consolidated banking groups at the last available date, thus losing evidence on the effects of all the intermediate consolidations that occurred before the last operation involving every parent bank. In the example above, we would have seen only bank $A B C$ over the entire period.

Moreover, with a traditional panel we would have introduced some distortion. Keeping in mind the example above, take the case of a firm $y$ which has always been a client of bank $C$, which merged in 2008 with $A B$ generating bank $A B C$. Recall also that bank $B$ was incorporated in 2004 into bank $A$. Using a traditional pro-forma panel of banks, over the whole period 19992009 we would only find bank $A B C$ in our sample, the only one existing at the end of the period. Its dummies $D_{M A}$ would be equal to 1 both in the blocks including 2004 (for the grouping of $A$ and $B$ ) and in those including the year 2008 (for the merger between $A B$ and $C$ ). In this hypothesis, firm $y$ would appear as a client of bank $A B C$ over the whole period; the dummies $D_{M A}$ would also be equal to 1 in the blocks including the year 2004, but these last dummies depend merely on a transaction between bank $A$ and $B$, and in 2004 firm $y$ was not a client of either of them. 
Table A - Variable Definitions and Expected Effects

\begin{tabular}{|c|c|c|c|}
\hline \multirow[b]{2}{*}{ Variable } & \multirow[b]{2}{*}{ Description } & \multicolumn{2}{|c|}{ Expected sign } \\
\hline & & $\begin{array}{l}\text { Variable } \\
\text { stand- } \\
\text { alone }\end{array}$ & $\begin{array}{c}\text { Interaction } \\
\text { term with } \\
\mathrm{D}_{\text {MAMULTI }}\end{array}$ \\
\hline \multicolumn{4}{|c|}{ Dependent variable (credit concentration in bank-firm relations) } \\
\hline Share $_{\mathrm{j}, \mathrm{i}, \mathrm{t}}$ & $\begin{array}{l}\text { Share of credit provided by bank } j \text { on the overall loans } \\
\text { used by firm } i \text { at time } t \text { (in percentage). }\end{array}$ & & \\
\hline \multicolumn{4}{|c|}{ Path dependence in credit concentration } \\
\hline Share $_{\mathrm{j}, \mathrm{i}, \mathrm{t}-\mathrm{3}}$ & $\begin{array}{l}\text { Share of credit provided by bank } j \text { on the overall loans } \\
\text { used by firm } i \text { at time } t-3 \text { (in percentage). }\end{array}$ & + & \\
\hline \multicolumn{4}{|l|}{ M\&A Variables } \\
\hline $\mathrm{D}_{\mathrm{MA}}$ & $\begin{array}{l}\text { The dummy is equal to } 1 \text { if bank } j \text { was involved in M\&As in } \\
\text { the three-year period expiring at time } t \text {. }\end{array}$ & $+/-$ & \\
\hline D MAMULTI $_{\text {M }}$ & $\begin{array}{l}\text { The dummy is equal to } 1 \text { if bank } j \text { was involved in M\&As in } \\
\text { the three-year period expiring at time } t \text { and, at time } t-3 \text {, it } \\
\text { was jointly financing the firm } i \text { with other banks involved } \\
\text { in M\&As. }\end{array}$ & - & \\
\hline \multicolumn{4}{|l|}{ Firm-level variables } \\
\hline Firm size & Log. of sales $(t-1)$. & - & \\
\hline Firm ROA & $\begin{array}{l}\text { Return on assets, measured by the ratio between earnings } \\
\text { before interests and taxes and total assets (percentage; } t \text { - } \\
\text { 1). }\end{array}$ & $+/-$ & \\
\hline Firm leverage & $\begin{array}{l}\text { Ratio between total assets and capital and reserves (value; } \\
t-1 \text { ). }\end{array}$ & $+/-$ & \\
\hline Rating & $\begin{array}{l}\text { Z-score provided by CADS (ranging from } 1 \text { to } 9 \text { and } \\
\text { signaling an increasing firm risk). }\end{array}$ & $+/-$ & - \\
\hline D $_{\text {SOUTH }}$ & $\begin{array}{l}\text { The dummy is equal to } 1 \text { if the firm is headquartered in } \\
\text { Italian Southern regions. }\end{array}$ & $+/-$ & - \\
\hline $\mathrm{D}_{\text {HITECH }}$ & $\begin{array}{l}\text { The dummy is equal to } 1 \text { if the firm belongs to a "high- } \\
\text { tech" sector, according to the OECD classification (OECD, } \\
\text { 2003). }\end{array}$ & $+/-$ & - \\
\hline DSMALLFIRM & $\begin{array}{l}\text { The dummy is equal to } 1 \text { if the firm has fewer } 60 \\
\text { employees (the median value of the whole sample). }\end{array}$ & + & - \\
\hline \multicolumn{4}{|l|}{ Bank-level variables } \\
\hline Bank size & Log. of total assets $(t-3)$ & - & \\
\hline Bank ROA & $\begin{array}{l}\text { Return on assets, measured by the ratio between earnings } \\
\text { before taxes and total assets (percentage; } t-3 \text { ). }\end{array}$ & $+/-$ & \\
\hline Bank risk & Ratio between bad loans and total loans (percentage; $t-3$ ). & $+/-$ & \\
\hline \multicolumn{4}{|c|}{ Local credit market controls } \\
\hline $\begin{array}{l}\text { Index of credit } \\
\text { concentration in the local } \\
\text { market (provinces) }\end{array}$ & $\begin{array}{l}\text { Herfindahl index measured on loans provided by banks in } \\
\text { the province in which firms are headquartered (range } 0 \text { - } \\
10,000 ; t \text { ). }\end{array}$ & $+/-$ & \\
\hline \multicolumn{4}{|c|}{ Relationship characteristics and geographical features } \\
\hline DPROX $_{\text {PR }}$ & $\begin{array}{l}\text { The dummy is equal to } 1 \text { if the financing bank } j \text { has got at } \\
\text { least one branch in the same municipality where firm } i \text { is } \\
\text { headquartered. }\end{array}$ & $+/-$ & $+/-$ \\
\hline $\mathrm{D}_{\text {DIST }}$ & $\begin{array}{l}\text { The dummy is equal to } 1 \text { if firm } i \text { belongs to an industrial } \\
\text { district. }\end{array}$ & $+/-$ & $+/-$ \\
\hline
\end{tabular}

